\title{
How Other Minorities Gained Access: The War on Poverty and Asian American and Latino Community Organizing
}

\author{
Jae Yeon Kim ${ }^{*}$ 糔 \\ Forthcoming at Political Research Quarterly
}

\begin{abstract}
In the early 20th century, Asian Americans and Latinos organized along national origin lines and focused on assimilation; By the 1960s and 1970s, community organizers from both groups began to form panethnic community service organizations (CSOs) that emphasized solidarity. I argue that focusing on the rise of panethnic CSOs reveals an underappreciated mechanism that has mobilized Asian Americans and Latinos-the welfare state. The War on Poverty programs incentivized non-black minority community organizers to form panethnic CSOs to gain access to state resources and serve the economically disadvantaged in their communities. Drawing on extensive archival research, I identify this mechanism and test it with my original dataset of 818 Asian American and Latino advocacy organizations and CSOs. Leveraging the Reagan budget cut, I show that dismantling the War on Poverty programs reduced the founding rate of panethnic CSOs. I further estimated that a $1 \%$ increase in federal funding was associated with the increase of the two panethnic CSOs during the War on Poverty. The findings demonstrate how access to state resources forces activists among non-primary beneficiary groups to build new political identities that fit the dominant image of the policy beneficiaries.
\end{abstract}

*I thank Paul Pierson, Taeku Lee, Eric Schickler, Irene Bloemraad, Robert Mickey, Margaret Weir, Mark Brilliant, Nicholas Duquette, Karen Tani, Cybelle Fox, Jonathan Simon, Morris Levy, Christian Collet, Sarah Anzia, Gabe Lenz, Chris Ansell, Andrew McCall, Rhea Myerscough, Neil O'Brian, Desmond Ang, Eric Guntermann, the editor and three anonymous reviewers at the Political Research Quarterly for their constructive comments. I am also grateful to Esther Kang, Angela Yip, Brenna Uyeda, Gregory Eng, Jenny Feng, and Isaac Nolan for their research assistance and to Dina Okamoto, Martha Bailey, and Nicholas Duquette for sharing their data. I acknowledge support from the American Democracy Project Fellowship, Berkeley Empirical Legal Studies Fellowship and the Blum Initiative's Fellows Program.

${ }^{\dagger}$ Direct correspondence to Jae Yeon Kim, Department of Political Science, 210 Barrows Hall 1950, Berkeley, CA 94720, E-mail: jaeyeonkim@berkeley.edu

† The original organizational data are available at https://doi.org/10.7910/DVN/FLUPBJ. All replication files can be found at https://github.com/jaeyk/regression-analysis-with-time series-data. 
The power of racial minorities in the US comes from the coordination of ethnic groups belonging to the same racial category. The US is becoming a minority-majority nation driven by the population growth of Latinos ${ }^{1}$ and Asian Americans. Latinos have now surpassed African Americans as the second-largest racial group, and Asian Americans have become the fastest-growing racial group in the US. However, demographics are not destiny. Asian Americans and Latinos both encompass disparate national origin groups. If these subgroups do not have a sense of internal unity, their population increase does not translate into a growth of their political power.

For this reason, understanding the conditions under which Asian Americans and Latinos became organized as coherent groups is important. Until a half century ago, the terms "Asian Americans" and "Latinos" themselves did not exist. In the early 20th century, Asian Americans and Latinos organized among their respective groups of national origin and focused on assimilation into American society. For instance, the Japanese American Citizens League (JACL) and the League of United Latin American Citizens (LULAC) ${ }^{2}$ were exclusively concerned about their own groups despite the fact that racial discrimination knows no bounds. Furthermore, the two organizations seemed to only concentrate on the middle class and American citizens among them (it was no coincidence that the term "citizens" was included in the names of both organizations).

Only in the late 1960s and 1970s did national origin groups from Asia and Latin America begin to form panethnic ${ }^{3}$ organizations that emphasized solidarity. Ethnic and class dimensions informed this change. These new organizations strengthened their focus on marginalized members: the poor, women, elderly, and children. Figure 1 describes this transition systematically, drawing on my original dataset on 818 Asian American and Latino advocacy and community service organizations (CSOs). The data divide panethnic organizations into three categories: advocacy, community service, and hybrid organizations. Advocacy organizations are involved in public and

1. I use the term "Latino" instead of more gender-neutral terms such as "Latina/o" or "Latinx" because this term is preferred by many of the organizations I collected in my dataset.

2. Although named as the League of Latin American Citizens, LULAC started as an organization primarily serving the interests of middle-class Mexican Americans in South Texas (Marquez 1993). The term "Latin" reflects more about the group members' cultural heritage.

3. Panethnicity is defined as "the construction of a new categorical boundary through the consolidation of ethnic, tribal, religious, or national groups" (Okamoto and Mora 2014, 221). 
electoral campaigns, litigation, and lobbying. CSOs provide social services to community members. Hybrid organizations are active in both advocacy and service ${ }^{4}$. In the figure, the Y-axis represents organizational population density ${ }^{5}$, which measures the number of organizations founded in each decade per population of one million, and the $\mathrm{X}$-axis indicates the decades. ${ }^{6}$ The figure presents three patterns. (1) Asian American and Latino organizations began to emerge in the 1960s. (2) Among different types of organizations, panethnic CSOs were the clear majority and (3) were the most densely populated in the 1970s. What explains the emergence and popularity of Asian American and Latino CSOs in the 1960s and 1970s?

Organizational founding trend

$\mathrm{Y}=$ The number of organizations founded in each decade per one million population

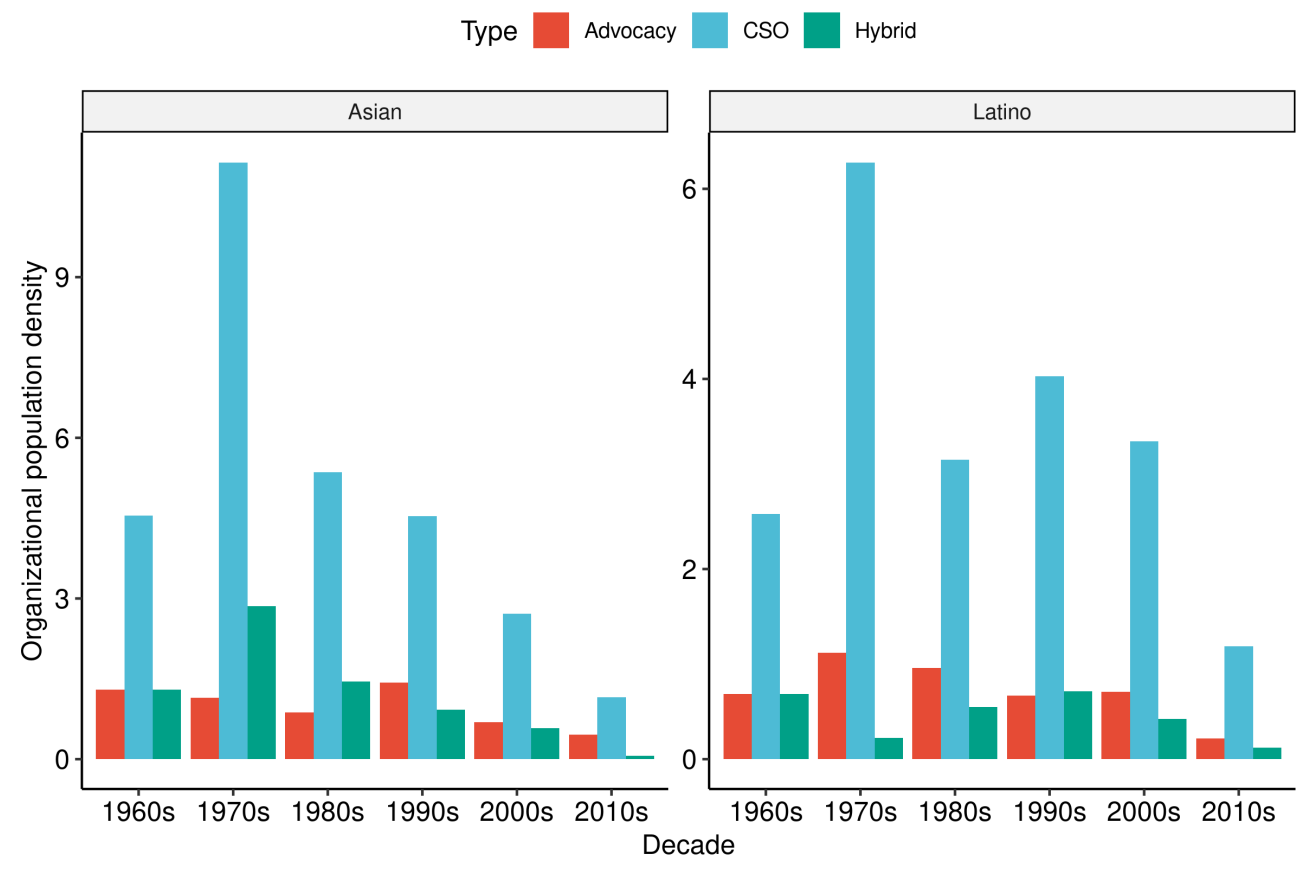

Figure 1: The founding trends of Asian American and Latino advocacy, community service, and hybrid organizations, 1960 - 2017. Source: the author

Previous studies do not explain these patterns. Recent studies on panethnicity show how networked relationships shaped the formation and expansion of Asian American and Latino panethnic

4. Minkoff (2002) coined the term hybrid organizations.

5. Influenced by bioecology, organization scholars define organizational population density as "the number of organizations in a population at time $t$ " (Barron 1999, 443).

6. This population adjustment is necessary, as the population size also influences organizational founding and is not constant over time. 
organizations (Mora 2014; Okamoto 2014). However, these studies share one common limitation: their exclusive focus on national panethnic organizations. CSOs, the majority of Asian American and Latino panethnic organizations, are mostly local organizations. Only 2\% of Asian American and $4 \%$ of Latino CSOs are based in Washington, DC or have "National" in their organization names (see Figure B.1 in Appendix B). Although most of these CSOs did not make headlines, they matter because they served marginalized members in the Asian American and Latino communities and trained new political activists and leaders by providing them with political knowledge, experience, and networks (Muñoz 1989; D. Chin 2001; G. Chin 2015; Ishizuka 2016; Duarte 2016).

I argue that the key to explaining the origin of these panethnic CSOs lies in the expansion of the American welfare state. After World War II, the American public became aware of the millions of Americans living in poverty amid the nation's postwar material prosperity (Harrington 1962). In response, in 1964, President Lyndon B. Johnson declared the War on Poverty and Congress enacted the Economic Opportunity Act to support his agenda. Between 1961 and 1972, federal aid programs to cities increased more than sixfold-from $\$ 3.9$ billion to over $\$ 26$ billion. These federal grants outweighed local social expenditure. In 1968, the total non-defense federal spending in Oakland, California was $\$ 95.5$ million, twice the city’s budget (Pressman 1975, 1-18). The War on Poverty programs sparked an expansion of panethnic CSOs by disrupting the political hierarchies within the national origin groups from Asia and Latin America. In the wake of the Immigration and Nationality Act of 1965, a major division emerged within these groups between, on the one hand, a relatively affluent old guard focused on pursuing assimilation, and on the other, a rapidly expanding and more economically disadvantaged base focused on gaining access to resources. The War on Poverty programs, which included community action agencies and the Model Cities Program, effectively tipped the scales toward the latter faction comprising Asian American and Latino activists by giving Asian American and Latino activists an opportunity to build their own organizations and transform the agenda of their communities (Orleck and Hazirjian 2011).

Although founding these organizations required substantial and long-term investment, these organizers took on this challenge to increase their groups' access to state resources. The Office of 
Economic Opportunity (OEO) was the agency responsible for the War on Poverty programs. The OEO allocated federal funds across states using a poverty index (see Appendix A). The spending within each state was strongly associated with both the poverty rate and the share of non-White people in each county (Bailey and Duquette 2014). However, Asian Americans and Latinos were non-primary beneficiary groups. According to the US Census, more than $99 \%$ of the US population was either black or white in 1960. Consequently, the federal government paid little attention to non-black minority groups. To gain federal support, the younger generation activists needed to document their conditions and increase the number of poor members in their grant proposals (Kuramoto 1976; Orozco, Schwartz, and Austin 2011). For them, Asian American and Latino CSOs were a strategic instrument that could be leveraged to take advantage of the federal funding and serve the economically disadvantaged in their communities.

In the rest of the article, I first develop a theory that explains the formation of panethnic CSOs as a strategic response to two organizational environmental changes: the availability of external financial resources (i.e., federal funding) and the extent of population growth. The underutilized archival materials at the Asian American ${ }^{7}$ and Chicano Studies Collections ${ }^{8}$ at the Ethnic Studies Library at the University of California, Berkeley provide rare insights into how Asian American and Latino community organizers strategically responded to the War on Poverty funding and policy implementation. Next, I test the theory with my original dataset of 818 Asian American and Latino advocacy organizations and CSOs. Using interrupted time series design and regression analysis, I establish the effect of federal grants on the founding rate of panethnic CSOs. Leveraging the Reagan budget cut, I show that dismantling the War on Poverty programs reduced the founding rate of panethnic CSOs. I further estimated that a $1 \%$ increase in federal funding was associated with the increase of the two panethnic CSOs during the War on Poverty. Past studies mentioned the impact of the War on Poverty on Asian American and Latino community organizing using interviews and case studies (Padilla 1985; Espiritu 1992; Wei 1993; Võ 2004; Herrera 2013). However, these examples are limited to demonstrating how generalizable the connection was. Based on the large-scale

7. For more information, see http://eslibrary.berkeley.edu/asian-american-studies-collection

8. For more information, see https://eslibrary.berkeley.edu/chicano-studies-collection 
original data collection, my findings provide the first systematic evidence of how the expansion of the welfare state transformed Asian American and Latino politics by activating the politics of recognition. It has long been argued in policy feedback literature that new policies, through vested interests, create a new politics (Schattschneider 1935; Pierson 1994; Campbell 2011). The case of Asian Americans and Latinos shows that for these historically disadvantaged groups, gaining access to - not protecting vested interests—motivated them to become politically active. Asian American and Latino activists organized the poor in their communities and began to form panethnic CSOs in the 1960s and 1970s to fit the dominant image of policy beneficiaries. This conclusion that access to state resources forces activists among non-primary beneficiary groups to take new political identities has broad implications for scholars of racial ethnic politics, intersectionality, policy feedback, and inequality, as well as activists and organizers.

\section{Theory}

Although interrelated, advocacy organizations and CSOs are two different species. Commitment to social justice played an important role in the founding of both types of organizations in Asian American and Latino communities (Wei 1993; Muñoz 1989). It is, however, crucial to note that founding a CSO is more capital-intensive than founding an advocacy organization. Building affordable houses, providing accessible healthcare, and expanding educational and employment opportunities all require substantial and long-term investments. Conversely, the variation in political advocacy activities is more strongly influenced by structural changes in political opportunity vis-àvis repression and openness of the government rather than funding availability (Eisinger 1973; Tilly 1978; McAdam 1982; Zepeda-Millán 2017).

Even among CSOs, there are different kinds. Whereas ethnic CSOs only serve the members of one ethnic group, panethnic CSOs serve the members of more than one ethnic group broadly defined by their shared racial status. Serving multiple ethnic groups that include a significant portion of

immigrants is costly as it requires capacity building. For example, if a Chinese healthcare center 
decided to serve Filipinos, it would need to hire additional staff who speak Filipino in order to cater to its new clients. From a cost perspective, it is difficult to understand why Asian-American and Latino community organizers began to prefer founding panethnic CSOs to founding ethnic CSOs in the 1960s and 1970s. Nevertheless, as Figure B.2 in Appendix B shows, founding panethnic CSOs became popular in the 1960s and 1970s. In Oakland, California, the Mexican American Unity Council was formed in 1964 to focus on advocacy. However, when it shifted its focus to service provision, it renamed itself the Spanish Speaking Unity Council and incorporated as a non-profit in 1967 (Orozco, Schwartz, and Austin 2011, 47-48) In Seattle, Washington, Inter*IM was formed in 1974 to stop evictions and build affordable housing in the Chinatown-International District, the city's historical Asian neighborhood. The Chinese Benevolent Association (CBA), the old guard Chinese organization, only protected the commercial interests of Chinatown. In contrast, Inter*IM fought to build affordable houses for low-income Chinese, Japanese, and Filipinos (D. Chin 2001; Santos 2002). Over the half-century, $76 \%$ of Chinese CSOs have turned into Asian American CSOs and $24 \%$ of Mexican CSOs into Latino CSOs. Why did Asian American and Latino organizers begin to take a costlier path in the 1960s and 1970s?

I argue that this transition is a function of the two organizational environmental changes: population growth (demand) and financial resources (supply). These two parameters are both influenced by policy changes. Asian American and Latino population growth were strongly influenced by immigration policy. When immigration policy was restricted to a country-quota system and favored whites (as in the late and early 20th century), the population growth of Asian Americans and Latinos was limited. When the country quota was eliminated by the Immigration and Nationality Act of 1965, also known as the Hart-Cellar Act, a wave of mass immigration from Asia and Latin America resumed (Tichenor 2009). Asian American and Latino community organizers raised funds in two different ways. They could rely on internal sources such as membership dues or donations or external sources such as government grants and philanthropic giving (see Appendix D). The availability of external financial resources increased substantially when the American welfare state expanded to grant them access during the War on Poverty. 
A different combination of these two parameters, the rate of population growth and the availability of financial resources, clarify the conditions under which founding panethnic CSOs was strategically preferred to founding ethnic CSOs by Asian American and Latino community organizers. The rate of population growth was low and only internal financial resources were available from the late 19th to the mid-20th century - the era of restrictive immigration. During this period, forming an ethnic CSO was optimal for a national origin group from Asia or Latin America since internal resources could not sufficiently serve non-ethnic group members. This logic explains why the foundation of mutual aid and benevolent societies such as the CBA, the JACL, and the LULAC at that particular time. Furthermore, as Strolovitch (2007) pointed out, the faction that holds power among the members of an organization decides whose interests the organization represents. Because these ethnic CSOs were financially dependent on internal resources, affluent members exerted disproportionate influence on organizational agendas. As these members had high stakes when things went awry, these early CSOs emphasized integration in the form of assimilation to avoid having direct confrontations with the hostile government and the white majority. This decision, however, also isolated and excluded the less fortunate members of their communities (Garza 1951; Hosokawa 1982; Umbach and Wishnoff 2008; Lozano 2018). The 1960s and 1970s were the period when the confluence of the immigration reform and the War on Poverty shifted leadership and transformed organizational strategy. The incumbent ethnic leaders, who maintained their influence through wealth and ethnic ties, began to lose their power to control agendas. When mass immigration from Asia and Latin America resumed, ethnic CSOs needed to substantially increase their efforts to meet the needs of additional clients. This explosively growing demand pushed ethnic CSOs to the limits of their capacity. In addition, when external financial resources became available, it was not easy for the incumbent ethnic leaders to take advantage of them, as doing so could create competition and threaten their exclusive control over community issues (Marquez 1993; D. Chin 2001; G. Chin 2015).

These policy changes favored the new generation of ethnic community leaders (Wong 1977). If 
the experiences of exclusion ${ }^{9}$, internment ${ }^{10}$, and deportation ${ }^{11}$ shaped the political memories of their parent generation, the Civil Rights and Black Power movement deeply influenced the political education of this new generation. These college-educated young leaders who spoke English fluently were able to advocate for the needs of their growing constituencies by leveraging the language of the Civil Rights (equal rights) Act and the Economic Opportunity (equal opportunities) Act.

Furthermore, the new leaders used the War on Poverty grants as seed money to start new organizations. ${ }^{12}$ For instance, Inter*IM, the Seattle's major Asian American CSO, was formed with the funding from the Model Cities Program and staffed by a part-time Model Cities Program coordinator. More importantly, the War on Poverty programs provided these new leaders with political knowledge, experience, and networks. Their skills to navigate the government bureaucracy were valued in new organizations focusing on external resources. Robert Santos was on the Model Cities Board of Directors before joining Inter*IM and served as its executive director from 1972 to 1989 (Santos and Iwamoto 2015, 58). Raul Yzaguirre transformed the National Council of La Raza (NCLR) from a local Mexican CSO in Phoenix, Arizona, into the nation's largest Latino organization while serving as its president and Chief Executive Officer from 1974 to 2004. He gained his formative political experience as a program analyst at the Migrant Division of the $\mathrm{OEO}^{13}$.

It is also important to highlight how the new ethnic leaders defined the boundaries of their political communities to understand how panethnic community organizing emerged as an outcome of the intersection between race and class. These individuals grew up in racially segregated and segmented Asian American and Latino neighborhoods. The American racial hierarchy put African Americans, Asian Americans and Latinos in segregated yet segmented locations. For instance, Chinatown is a misnomer as it is adjacent to other Asian ethnic enclaves such as Japantown or Manilatown, and the boundary between them is porous. In 1951, the Seattle Chinatown area was

9. The Chinese Exclusion Act was enacted in the US in 1882 and repealed in 1943 when China became a US ally during World War II.

10. Japanese Americans, including US born citizens, were incarcerated during World War II (1942-46).

11. During the Depression, more than 500,000 Mexicans, including US born citizens, were deported to Mexico (Marquez 1993, 20).

12. The Pilipino People's Far West Convention, August 30, September 1, 1974, University of California, Los Angeles. Ethnic Studies Library, University of California, Berkeley.

13. The NCLR Newsletter, July 1974, Ethnic Studies Library, University of California, Berkeley 
renamed the International District to correctly reflect this fluid nature of the neighborhood (D. Chin 2001). The same explanation can also be applied to Latino inner-city barrios (neighborhoods) (Arreola 2009). San Francisco's Mission District, the city's Latino barrio, is the place where both Mexicans and Central Americans settled (Quesada 1999). When young leaders in non-black communities formed panethnic CSOs, patterns of both racial segregation and segmentation mattered since issues concerning these organizations were deeply local. Poverty was the main concern of these new ethnic leaders. However, these issues were also framed in racial terms (panethnic, precisely) because that was how the boundaries of the local communities were drawn. The new ethnic leaders strategically responded to the policy challenges, but which issues they could focus on and which groups they aligned with were determined by their past historical legacies (J. Y. Kim 2020). Table 1 summarizes how the prevailing type of CSOs changed in line with shifts in population growth and funding sources.

\begin{tabular}{l|l|l}
\hline & Internal financial resources & External financial resources \\
\hline Low population growth & $\begin{array}{l}\text { Ethnic CSOs emerged and fo- } \\
\text { cused on assimilation }\end{array}$ & $\begin{array}{l}\text { Ethnic CSOs lost their influ- } \\
\text { ence }\end{array}$ \\
\hline High population growth & $\begin{array}{l}\text { Ethnic CSOs lost their influ- } \\
\text { ence }\end{array}$ & $\begin{array}{l}\text { Panethnic CSOs emerged and } \\
\text { focused on solidarity }\end{array}$ \\
\hline \hline
\end{tabular}

Table 1: Population growth, funding sources, and the prevailing type of CSOs

The above argument is grounded in the reading of secondary sources as well as my own archival research. The following archival evidence reveals how the new ethnic leaders in Asian American and Latino communities discussed panethnic CSOs as a strategic instrument to gain state support. These leaders understood that the salience of their issues was derived from their status as viable minorities. CSOs across the country needed unified labels (Asian Americans and Latinos) to expand their constituencies and fortify their political strength. Many conferences and workshops were organized to share and develop this new strategy. The Mid-Atlantic Conference on Community Concerns of Asian Americans was held in New York City on April 26-27, 1974. ${ }^{14}$ In his welcoming

14. Awareness and Action in the '70s: Mid-Atlantic Conference on Community Concerns of Asian Americans, April 26-27, 1974, New York. Ethnic Studies Library, University of California, Berkeley. 
remark, Rev. Alfred Akamatsu, the founder of the anti-fascist Japanese American Committee in New York, stressed the fact that invisibility is a weakness:

As we struggle to make our demands known, however, we are forced to realize that the only realistic way for a small minority like ours is to band together with like-minded people for greater effectiveness. This, I take it, is the underlying meaning of this conference_-uniting all Asian Americans together.

In her keynote speech, Patsy Mink (D-Hawaii), a former member of the US House of Representatives, also referred to the lack of unity among Asian national origin groups as a major obstacle:

One of the difficulties that we [Asian Americans] face, certainly it's my experience in Washington, is that so little is ever heard of Asian Americans as a united group. One of the big struggles in HEW (the Department of Health, Education, and Welfare) and other departments in government has been to get them to recognize the existence of Asian Americans as a viable ethnic minority.

The situation Latinos faced was not much different. In 1969, the Cabinet Committee on Opportunities for Spanish-Speaking People (CCOSP) was established as Johnson's effort to please Latino leaders. Nevertheless, Latino leaders soon realized that the CCOSP was incapable of delivering its promised benefits. William P. Vasquez, president of La Causa Comun, a Puerto Rican CSO, pointed out this issue in a Congressional hearing held in $1973^{15}$ :

Over the past few years and months, numerous hopes and aspirations have been terminated. The greatest casualty of the political processes of this period has been the belief that Latinos would be systematically included in the economic and social developments

15. U.S. Congress House of Representatives. Civil Rights and Constitutional Rights Subcommittee of the Committee on the Judiciary. Equal Opportunities for Spanish-speaking People: Hearings before the Civil Rights and Constitutional Rights Subcommittee. 93rd Cong., 1st sess, July 11 and July 19, 1973, 55-56. 
and policies of our Federal Government. All too many of us [Latino leaders] had presumed that the Federal Government, in establishing a Cabinet Committee, was making its first step in that direction. Instead, we Latinos have had to begin to realize that the Cabinet itself did not grow with the times. Its authority, power, and responsibility are virtually the same as in 1969.

The key problem was the lack of visibility of Latino populations in government reports and statistics. This omission mattered because population counts were an important factor for federal grant allocation. In 1974, when the Geography Division of the US Bureau of Census released the Urban Atlas series, which displayed the population trends in the US urban areas, it did not include the percentage of people of Spanish origin. Census Bureau director Vincent Barabba explained, during the planning stage, that the Bureau considered the inclusion of a map showing the Spanish origin population, but dropped it due to the budget constraint. Raul Yzaguirre, then director for the NCLR, criticized the Bureau's decision as "exactly the thing that has kept Hispanic Americans from becoming an identifiable population". ${ }^{16}$ In an article published in the NCLR newsletter in 1980, Raul Yzaguirre stressed why Latino CSOs mattered to overcome the Latino's invisible status ${ }^{17}$ :

Hispanics [Latino CSOs] are proving that they can organize and conquer the government bureaucracies with the same sophistication and professionalism as any other group within the population. . . . These [doubts and skepticism regarding Latino community organizing] are real and we had best not ignore them. But there is also another reality. The reality is exemplified in the saga of determined Hispanics [Latino CSOs] who withstood the ridicule, who outwitted the bureaucrats, who learned the rules, who organized strong constituencies, and who now lead in rebuilding hope and awareness in our barrios and colonias.

16. The NCLR newsletter, October 1974, 3. Ethnic Studies Library, University of California, Berkeley.

17. The NCLR newsletter, September/October 1980, 2. Ethnic Studies Library, University of California, Berkeley. 


\section{Hypotheses}

I derive two observable implications from the theory. The first hypothesis emphasizes the external resource dependency of panethnic CSOs. The second hypothesis highlights that panethnic CSOs and advocacy organizations were produced by different mechanisms.

- Hypothesis 1: Federal funds, available to minority CSOs, positively influenced the founding rate of panethnic CSOs in the 1960s and 1970s.

- Hypothesis 2: These funds did not influence the founding rate of panethnic advocacy organizations in the same period.

\section{Empirical Strategies}

To begin, I define both the treatment (federal grants) and the dependent variable (organizational founding rate). When federal funds became more available both in terms of relative amount and accessibility, the treatment increased. When federal funds became less available by the same definition, the treatment decreased. The outcomes of interest are the founding rate of panethnic CSOs (H1) and advocacy organizations (H2).

Identifying the effect of the treatment on the dependent variable is difficult because so many policies were introduced in the 1960s. The theory identified civil rights and immigration reform as potential confounders. The objective of this research design is to isolate the effect of federal funding from that of these major confounders. The effects can be untangled by zeroing in on the discontinuity in time - the Reagan budget cut. If the confounded treatment effect is an issue, this problem can be addressed by identifying the time point when the treatment changed but the confounders did not. The treatment effect can be estimated by comparing the patterns of the dependent variable before and after the intervention. This research design is called an interrupted time series (ITS) design (Campbell and Ross 1968; Cook and Campbell 1979).

The Reagan budget cut is an ideal setting to apply the ITS design and estimate the reduced 
treatment effect. If the federal grants played a positive role in the creation of Asian American and Latino CSOs at $t_{-1}$, then their substantial reduction at $t$ (the budget cut) should generate a negative impact on the organizational founding rate at $t_{+1}$. The ITS design leverages the fact that the treatment and some key confounders moved in the same direction before the intervention and the opposition directions after the intervention. Although President Reagan was committed to reducing the role of the federal government in civil rights, he succeeded only to a limited extent. The administration's efforts to limit the power of the federal government were, however, successful in certain areas of social policy programs. During the Reagan years, Congress repealed the Economic Opportunity Act and cut the budgets for the War on Poverty programs (Orleck 2011, 7). Programs such as Medicare that focused on individual assistance survived the crisis and even expanded in scope. However, community empowerment programs benefiting CSOs could not escape from the budget cut (Danziger and Haveman 1981), and institutional barriers to gain access to state resources increased (Naples 1998, 47-48) (see Appendix E).

This sudden tightened access to and slashing of federal grants was largely unexpected from the perspective of Asian American and Latino community organizers. Proving this mechanism is crucial to validate that 1981 , the year Reagan came into office, is a proper cutpoint. If information about the Reagan budget cut was widely available among these community organizers before 1981, an earlier year would be better suited as the cutpoint. I test this assumption by tracing the number of articles on Reagan from the records of The International Examiner (1976 - 1987) and Agenda (1971 - 1981). The International Examiner, an Asian American newspaper rooted in Seattle, was founded in 1974 and has functioned as a public forum for Asian American community organizers in Seattle and the Northwest. Agenda, the official newsletter of the nation's largest Latino organization, served a similar role for Latino community organizers across the US. The text analysis of these articles shows that when these Asian American and Latino public forums address Reagan, they also mention the financial challenges facing CSOs (see Figure F.1 in Appendix F). I define the end point of the shock period using the change point estimation method (Andrews 1993; Zeileis et al. 2003) (see Appendix G). 
I estimate the key parameter - the change in the slope of the dependent variable around the cutpoint. ${ }^{18}$ Typically, a segmented regression model is used to estimate these parameters. In Model $1, Y$ is the dependent variable at time $t$ or the number of organizations founded in each year. Year is the year variable. $X$ indicates intervention, which is coded 0 in the pre- and 1 in the post-intervention period. Type indicates either organization type advocacy, community service, or hybrid organizations. Group indicates either group category Asian American or Latino organizations. These variables are aggregated and measured at the national level. $\beta_{0}$, the intercept, represents the baseline level of the dependent variable, and $\beta_{1}$ represents the pre-intervention trend. $\beta_{2}$ indicates the level change, and $\beta_{3}$ indicates the slope change following the intervention (Bernal, Cummins, and Gasparrini 2017, 350-351). Hypotheses 1 and 2 both focused on the organizational founding rate, so I focus on estimating $\beta_{3}$ : the slope change.

$$
Y_{t}=\beta_{0}+\beta_{1} \text { Year }+\beta_{2} X_{t}+\beta_{3} \text { Year } \times X_{t}+\beta_{4} \text { Type }_{t}+\beta_{5} \text { Group }_{t}+\varepsilon
$$

As for the next step, I fit an ordinary least squares (OLS) regression, an OLS regression with logged dependent variable, a Poisson, and a negative binominal model to the data and select the best fitting model based on its Akaike information criterion (AIC) score, which estimates the trade-off between model accuracy and complexity (see Appendix I).

I first report the result of the ITS design analysis. Next, I visualize how the result varies by organization type as a way to confirm both Hypotheses 1 and 2. I argue that only the founding rate of Asian American and Latino CSOs (not that of their advocacy counterparts) was negatively impacted by the Reagan budget cut. Prior to the Reagan budget cut, the NCLR supported both its local CSO affiliates and advocacy in Washington, DC. During the budget crisis, the NCLR reduced their focus to advocacy (Martınez 2008, 82). This case illustrates how the tight budget constraint has differential impacts on service-oriented work as opposed to advocacy. The data analysis will demonstrate that this case is part of a broad pattern. In addition, I will show that the result does not

18. Because the cumulative number of Asian American and Latino organizations constantly increased, comparing the level change before and after the intervention offers little information on the impact of the Reagan budget cut. 
vary by group category when I limit the data to panethnic CSOs. This test reassures that the impact of the intervention is not conditional on a specific group.

Because the ITS design analysis estimates the reduced treatment effect, it may not capture the full effect of the federal grants on the growth of panethnic CSOs. To address this concern, I estimate how the predictive power of federal funding on the founding rate of panethnic CSOs changed over time, especially around the cutpoint (see Appendix J). I also calculate bootstrapped confidence intervals for these coefficients to indicate their uncertainty.

$$
Y_{t}=\beta_{0}+\beta_{1} \mathrm{X}_{t}+\beta_{2} \text { Population }_{t}+\beta_{3} \text { Group }_{t}+\beta_{4} \text { Presidency }_{t}+\beta_{5} \text { Senate }_{t}+\beta_{6} \text { House }_{t}+\varepsilon
$$

\section{Data}

\subsection{Asian American and Latino Advocacy Organizations and CSOs}

There exists no comprehensive ready-made dataset on Asian American and Latino advocacy organizations and CSOs. Existing Asian American or Latino organizational directories solely cover organizations in particular regions or national organizations. Therefore, between May 2017 and August 2017, I collected data from scratch on Asian American and Latino advocacy organizations and CSOs. I created my initial dataset drawing on four directories: the Encyclopedia of Associations (EA) - National Organizations of the US, the Encyclopedia of Associations - Regional, State, and Local Organizations of the US, the National Directory of Nonprofit Organizations, and the National Center for Charitable Statistics (NCSS). Collecting data from multiple sources is useful to reduce sampling bias. Past studies (Minkoff 1995; Okamoto 2014) also used EA data to trace the formation of racial and ethnic organizations. NCSS data are useful for obtaining information on more recently founded organizations. The total number of Asian American organizations in the dataset is 299, and there are 519 Latino organizations.

To begin with, I used the following search strategy to find the organizations of interest in the 
data sources. For the Asian American side, I used the following search queries: "Asian," "Asian American," and "Asian Pacific American." For the Latino side, I used "Hispanic," "Latino," "Latina," and "Spanish." The databases find organizations that match these search queries either by their titles or descriptions. $86 \%$ of Asian American organizations and $85 \%$ of Latino organizations in the dataset were found through this initial search. To avoid missing ethnic organizations that had become panethnic organizations (or served panethnic constituencies but did not use panethnic markers in their titles), I also searched "Chinese," "Chinatown," "Japanese," and "Filipino" on the Asian American side and "Mexican," "Chicano," "Chicana," "Puerto Rican," “Cuban," "la Raza,"19 and "centro" on the Latino side. In the 1960s and 1970s, it was not clear whether organizing Asian Americans or Latinos would be successful. In addition, if an organization was deeply rooted in a particular ethnic community, transitioning from an ethnic to panethnic organization was not easy because the organization needed to maintain its base while appealing to new constituents.

Finally, I use primary and secondary sources to note Asian American and Latino advocacy and community service organizations that did not use panethnic or ethnic markers in their titles. For instance, the ASPIRA Association, a Latino CSO focusing on educational access is not searchable by either ethnic or panethnic markers. The number of these uniquely named organizations is far smaller than that of the other two types of organizations (only $7 \%$ of the Asian American and $3 \%$ of the Latino organizations in the dataset).

To increase reliability, I exclude organizations for which I could not find any information online beside IRS records as of August 2017. I also omit foundations, chambers of commerce, mutual aid organizations, labor unions, and religious organizations because they have different primary revenue sources such as membership dues and donations. ${ }^{20}$

One limitation with this dataset is the recency bias. The directories do not include all the defunct organizations. Consequently, the dataset only includes organizations that (1) survived and

19. Although la Raza literally means "the race" and refers to the Hispanophone population, this term was particularly favored by the Chicano/Chicana activists in the Mexican American community (Alaniz and Cornish 2008).

20. Ethnic chambers of commerce and labor unions could be seen as advocacy organizations. However, I have not included them in the analysis because I am primarily interested in the type of ethnic advocacy organizations that are similar to CSOs, with the exception of their relative dependence on external financial resources. 
(2) appeared in the data sources in 2017. Nevertheless, it is important to note that the recency bias favors the null hypothesis because the survival rate would be lower during the War on Poverty than after it. Many organizations founded during the War on Poverty period were forced to close during the Reagan era. Take the case of Seattle's Chinatown/International District as an example. In March 1981, when the news on the Reagan budget cut came out, The International Examiner declared that the "survival of [local] social agencies" was at stake. Because Reagan decided not to reauthorize the Economic Opportunity Act, six Asian American CSOs in the area had to collectively raise $\$ 213,750$ during the last three months of $1981 .^{21}$ For small CSOs operating in one of the poorest neighborhoods in the city, this financial threat was substantial. ${ }^{22}$ As the recency bias in the data makes the hypothesis testing conservative, it only strengthens the credibility of positive findings.

\subsection{Administrative and Other Data}

As for the time series data used in the main analysis, the federal budget data come from the Budget of the US Government, Fiscal Year 2017 Historical Tables. Asian American and Latino population data come from the US census. Party control of the presidency and Congress data come from Russell D. Renka's website. ${ }^{23}$ As for the cross-sectional data used in the discussion section, the county-level Asian and Latino population data ${ }^{24}$ and the county-level poverty rate estimates ${ }^{25}$ both come the US Historical Census Statistics. The county-level data on the OEO spending were collected by Bailey and Duquette (2014).

21. Chew, Ron, "Federal Cutbacks Threaten Survival of Social Service Agencies", The International Examiner, March 17, 1981

22. For reference, the annual budget for the Emergency Meal Voucher Program operated by the Inter*IM, an Asian American CSO in the area, was \$36,000 in 1978. Inter*IM staff, "What Inter*IM is doing for you", The International Examiner, March 31, 1978, 10

23. For more information, see http://cstl-cla.semo.edu/rdrenka/ui320-75/presandcongress.asp.

24. For more information, see https://www.census.gov/library/working-papers/2005/demo/POP-twps0076.html

25. For more information, see https://www.census.gov/library/visualizations/timeseries/demo/census-poverty-tool. html 


\section{Data Analysis}

I begin by detecting and replacing outliers in the dependent variable. Outliers are undesirable because they can violate the linearity and normality assumption of an OLS model and produce incorrect regression coefficients and standard errors (see Appendix $\mathrm{H}$ ).

The next step is the interrupted time series analysis. I fitted the OLS regression, the OLS regression with a logged dependent variable, the Poisson, and the negative binomial model to the data. Based on the AIC scores, the OLS model with a logged dependent variable fits the data best (see I.1 in Appendix I). In Table 2, Model 1 is the base model which includes organization type covariate. Model 2 adds group category covariate. The interaction term between year and the intervention variable estimates the slope change. The table shows the regression coefficient of this interaction term is statistically significant measured by the p-value of 0.1 in Model 1 and 0.05 in Model 2. The negative sign indicates the negative impact of the intervention on the organizational founding.

\begin{tabular}{|c|c|c|}
\hline & \multicolumn{2}{|c|}{ Dependent variable: } \\
\hline & \multicolumn{2}{|c|}{ Founding rate (logged) } \\
\hline & Model 1 & Model 2 \\
\hline Year & $0.059^{* * *}(0.016)$ & $0.066^{* * *}(0.016)$ \\
\hline Intervention & $67.587^{*}(34.569)$ & $80.450^{* *}(33.919)$ \\
\hline $\mathrm{CSO}$ & $1.081^{* * *}(0.094)$ & $1.096^{* * *}(0.092)$ \\
\hline Hybrid & $-0.059(0.105)$ & $-0.054(0.102)$ \\
\hline Latino & & $0.247^{* * *}(0.077)$ \\
\hline Year:Intervention & $-0.034^{*}(0.018)$ & $-0.041^{* *}(0.017)$ \\
\hline Constant & $-116.501^{* * *}(31.796)$ & $-130.508^{* * *}(31.286)$ \\
\hline Observations & 178 & 178 \\
\hline $\mathrm{R}^{2}$ & 0.570 & 0.594 \\
\hline Adjusted $\mathrm{R}^{2}$ & 0.557 & 0.580 \\
\hline Akaike Inf. Crit. & 281.346 & 273.025 \\
\hline
\end{tabular}

Table 2: ITS design analysis

I conduct a more careful hypothesis testing through the subgroup analysis. The theory implies 
that the intervention would have negatively affected the organizational founding rate of panethnic CSOs but not that of their advocacy counterparts. In Figure 2, the X-axis indicates the year variable, the Y-axis the logged count of organizations founded per each year, and the blue line the fitted values of the models. The top panel in the figure displays this contrasting pattern. Consistent with Hypothesis 2, the negative slope change is present in panethnic CSOs but not advocacy organizations. In the bottom panel, I limit the data to panethnic CSOs and confirm that the pattern is not conditional to a specific group.

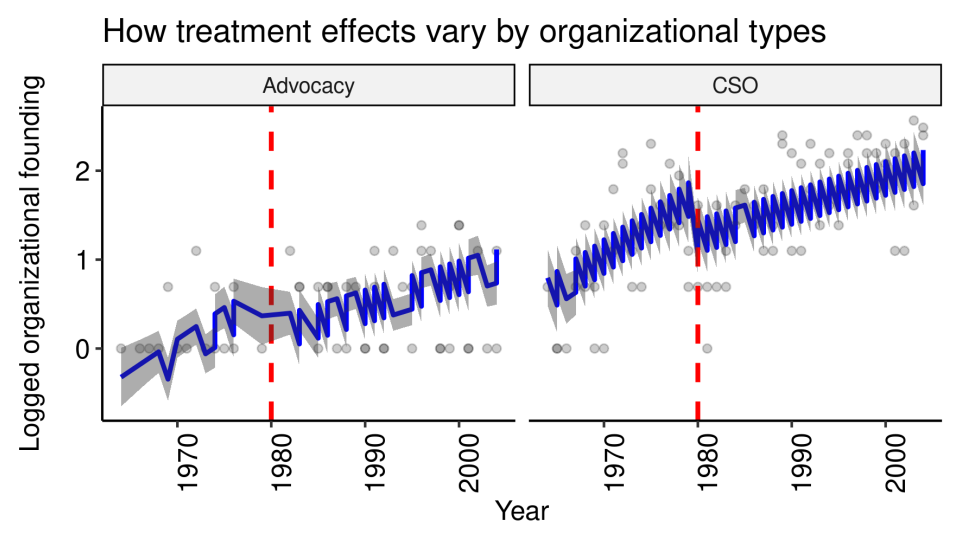

How treatment effects vary by groups Only included CSOs

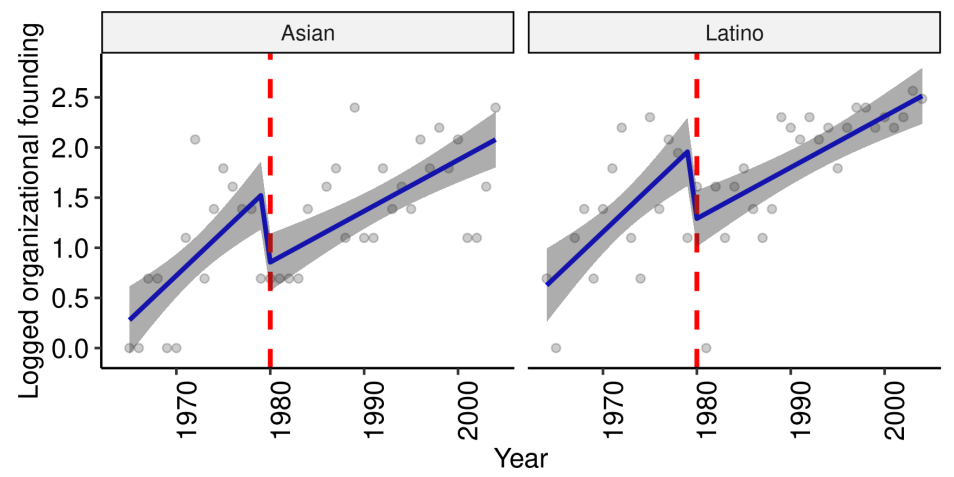

Figure 2: Subgroup analysis

Nevertheless, a measurement problem persists. The intervention measure, a dummy variable, is rough as it could capture not only the impact of the Reagan budget cut but that of other concurrent events such as the decline of the Civil Rights and Black Power Movement. To address this concern, I examine how the predictive power of federal funding on the founding rate of panethnic CSOs changed over time, especially around the cutpoint. Specifically, I estimated how the coefficients of 


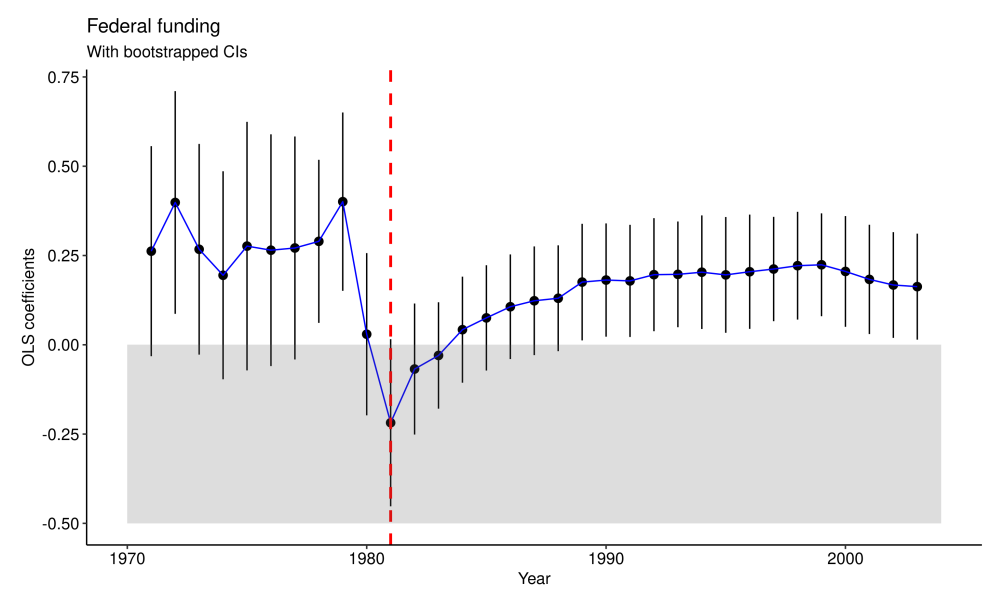

Figure 3: Changes in the coefficients of federal funding with bootstrapped CIs

federal funding in the OLS with a logged dependent variable changed as I extended the data from 1970 to $2004 .^{26}$ The point and line plot in Figure 3 show that the coefficients of federal funding were positive up to the cutpoint. They became almost zero after the cutpoint. This abrupt change demonstrates that federal funding positively contributed to the founding rate of panethnic CSOs before the Reagan budget cut, and its role diminished right after the intervention. To measure the uncertainty of the point estimates, I added confidence intervals using bootstrapping. Figure 3 shows that the coefficient change around the cutpoint is statistically significant.

Another limitation of the ITS design analysis is the reduced treatment effect. The slope change indicates that the decrease of one panethnic CSO is associated with the Reagan intervention. The full impact of the War on Poverty programs on the creation of panethnic CSOs could be larger than this estimate. To examine this issue, I ran a regression model including organizational, demographic, and partisan covariates based on the subset of the data including observations up to the year 1980 (see Model 1 in Table 3). The exponentiated regression coefficient of federal funding variable indicates that a $1 \%$ increase in federal funding is associated with the increase of the two panethnic CSOs during the War on Poverty. To check robustness, I examined heteroskedasticity, autocorrelation and the influence of remaining outliers (see Appendix K). In the table, Model 2 follows the specification of Model 1 except that it uses the robust Newey-West variance estimator

26. For instance, the 1970 data are the subset of the original data including observations up to the year 1970 . 
Dependent variable:

Founding rate (logged)

\begin{tabular}{lccc} 
& OLS & $\begin{array}{c}\text { OLS } \\
\text { with robust SEs } \\
\text { Model 2 }\end{array}$ & Robust regression \\
& Model 1 & Model 3 \\
\hline Federal funding & $0.325^{* * *}(0.103)$ & $0.325^{* * *}(0.086)$ & $0.325^{* * *}(0.083)$ \\
Population growth & $0.027(0.174)$ & $0.027(0.090)$ & $0.022(0.106)$ \\
Latino & $0.397(0.596)$ & $0.397(0.302)$ & $0.415(0.419)$ \\
Presidency & $-0.178(0.187)$ & $-0.178(0.240)$ & $-0.180(0.201)$ \\
\hline Observations & 32 & & 32 \\
$\mathrm{R}^{2}$ & 0.498 & & 0.472 \\
Adjusted $\mathrm{R}^{2}$ & 0.423 & & 0.394 \\
\hline \hline Note: & & & ${ }^{*} \mathrm{p}<0.1 ;{ }^{* *} \mathrm{p}<0.05 ;{ }^{* * *} \mathrm{p}<0.01$
\end{tabular}

Table 3: Time series regression analysis

to account for heteroskedasticity. Model 3 fits a robust regression model to the same data used in Model 1 to account for unusual observations. These model outputs are only marginally different and thus negligible. The statistical significance of federal funding is stable, and the coefficient of federal funding variable is identical across the three models.

\section{Discussions}

A misspecification problem may persist because the covariates specified in the regression models still miss some confounders. These unobserved variables lead to a biased regression coefficient. I ran a sensitivity test using the sensemakr package in R (Cinelli and Hazlett 2019) to estimate the fragility of this regression coefficient. The test result shows that if unobserved confounders, orthogonal to covariates, explain more than $34.65 \%$ of the residual variance of both the treatment and the dependent variable, they could reduce the regression coefficient of federal funding to 0 . In the previous time series analysis, the variables are aggregated and measured at the national level. However, local level variables may play a critical role. Even though federal grants might influence the founding rate of panethnic CSOs, they are unable to drive the creation of these local 
organizations if the population in the community does not exist in that particular locality. Therefore, local level demographic and other related control variables are needed to address omitted variable bias.

I tackled this challenge by using the county-level data on the OEO grants (1964-1968) collected by Bailey and Duquette (2014). Bailey and Duquette examined the association between the countylevel variation in OEO spending with more than twenty demographic, political, and economic measures. Their study demonstrates roughly $30 \%$ of the within-state variation in OEO spending is explained by two variables: the poverty rate and the share of non-White populations in counties. The result of this systematic investigation shows that among local-level potential confounders, the poverty rate and the share of Asian American and Latino population are most critical. For this reason, I combine the OEO grant data with the county-level US census data on Asian and Latino population percentage and the overall poverty rate $^{27}$ and my original data on Asian American and Latino CSOs. Based on this merged data, I then regress the cumulative number of Asian American and Latino CSOs in 1981 (the year when the OEO ceased to operate) on the OEO grants and the demographic and economic covariates. The results demonstrate that the inclusion of local-level demographic factors does not alter the main findings (see Appendix L).

Finally, I discuss the scope of implications drawn from this study. The raw points in Figure 2 show that the cumulative number of Asian American and Latino organizations continued to grow after the drop during the Reagan intervention. The theory argues that the formation of panethnic CSOs is driven by both the availability of external financial resources (i.e., federal funding), and the extent of population growth. The second factor, the continuous explosive growth of Asian American and Latino populations, may explain this pattern. In Figure 1, the organizational founding rate is adjusted for population growth. In this case, it is clear that the 1970s were the high point for the formation of Asian American and Latino CSOs.

Additionally, the theory does not preclude the possibility of the formation of inter-racial CSOs. In a place where two racial minority groups shared a neighborhood, an inter-racial CSO emerged.

27. The 1980 Census data was selected as before then Hispanic was not used as a census category (Rodriguez 2000). 
The Western Addition Community Organization was founded in 1977 in San Francisco on the coalition between African Americans and Japanese Americans. The two groups shared the Western Addition through a historical accident. San Francisco's Japantown was originally neighboring Chinatown and forced to relocate to the Western Addition due to the 1906 earthquake. When the Japanese were interned during World War II, African Americans moved in the Western Addition and these two groups formed the mixed neighborhood. In the 1960s and 1970s, cases like the Western Addition were rare because in most other places African Americans, Asian Americans, and Latinos formed rather distinct neighborhoods (J. Y. Kim 2020, 15). A recent demographic trend in the US metropolitan areas shows a steady increase of mixed-race and mixed-ethnicity neighborhoods (Frey and Farley 1996). If this trend continues, the formation of CSOs based on inter-racial coalitions would also become more likely.

\section{Conclusion}

The findings provide the first systematic evidence on the positive impact of the War on Poverty programs on the rise of Asian American and Latino CSOs in the 1960s and 1970s. The evidence highlights the importance of the welfare state to understand some of the most fundamental questions in racial and ethnic politics: why panethnic groups such as Asian Americans and Latinos exist, and why these new groups and identities emerged at particular times in US history. This reveals how Asian American and Latino community organizers used a broad collective identity to overcome their invisible status and gain access to state resources.

Although the empirical puzzle focuses on the formation of panethnic CSOs during the War on Poverty, the theory tells a much broader story of how non-target groups gained access to state resources through organizational means. Policy feedback literature has long argued that new policies, through vested interests, create a new politics (Schattschneider 1935; Pierson 1994; Campbell 2011). The case of Asian Americans and Latinos is interesting because these groups were not formed to defend their vested interests by protecting existing policies. They were formed to benefit from 
new policies when their inclusion was not clear. The mix of archival research and quantitative analysis demonstrates how Asian American and Latino community organizers responded their groups' ambiguous status and the extent to which the introduction of these programs influenced the formation of their respective CSOs.

The findings also demonstrate why scholars of racial and ethnic politics, intersectionality, and inequality as well as activists and organizers need to pay close attention to specific policy designs to understand the conditions under which organizers among disadvantaged groups adopt new political identities. In some cases, the way a dominant group structures the positions of subordinate groups is clear and explains the terms under which ethnic and racial groups relate to each other (Omi and Winant 1986; C. J. Kim 1999, 2003). This argument explains how colonial states formed panethnic groups by lumping different ethnic groups together (Nnoli 1978; Young 1976; Nagata 1979; Hirschman 1987). In US politics, this coercive mechanism is often highlighted because it explains the process in which African-American group consciousness was formed through the legacy of slavery and Jim Crow (Tate 1994; Dawson 1994). In other cases, the classification schemes are rather ambiguous. This approach is not negligible because, from the state's perspective, designing the whole taxonomy, collecting detailed demographic information, and serving and controlling target groups are all costly operations. For this reason, the government officials who manage this comprehensive process have incentives to ignore non-primary groups and leave them ambiguously defined. This blindside by the state is the key to explaining why Asian American and Latino organizations emerged during the War on Poverty and why this trend was driven by panethnic CSOs. To seize the opportunity, activists among economically disadvantaged Asian Americans and Latinos had to become organizers and build new political identities to fit the dominant image of policy beneficiaries. 


\section{References}

Alaniz, Yolanda, and Megan Cornish. 2008. Viva La Raza: A History of Chicano Identity and Resistance. Seattle, WA: Red Letter Press.

Andrews, Donald W.K. 1993. "Tests for Parameter Instability and Structural Change with Unknown Change Point." Econometrica 61 (4): 821-856.

Arreola, Daniel, ed. 2009. Hispanic Spaces, Latino Places: Community and Cultural Diversity in Contemporary America. Austin, TX: University of Texas Press.

Bailey, Martha J, and Sheldon Danziger. 2013. Legacies of the War on Poverty. New York: Russell Sage Foundation.

Bailey, Martha J, and Nicolas J Duquette. 2014. How Johnson Fought the War on Poverty: The Economics and Politics of Funding at the Office of Economic Opportunity. Technical report. National Bureau of Economic Research.

Barron, David N. 1999. "The Structuring of Organizational Populations.” American Sociological Review, 421-445.

Bernal, James Lopez, Steven Cummins, and Antonio Gasparrini. 2017. "Interrupted Time Series Regression for the Evaluation of Public Health Interventions: a Tutorial.” International Journal of Epidemiology 46 (1): 348-355.

Breusch, Trevor S, and Adrian R Pagan. 1979. “A Simple Test for Heteroscedasticity and Random Coefficient Variation.” Econometrica: Journal of the Econometric Society, 1287-1294.

Campbell, Andrea Louise. 2011. How Policies Make Citizens: Senior Political Activism and the American Welfare State. Princeton, NJ: Princeton University Press.

Campbell, Donald T, and H Laurence Ross. 1968. "The Connecticut Crackdown on Speeding: Time-Series Data in Quasi-Experimental Analysis.” Law and Society Review, 33-53. 
Chin, Doug. 2001. Seattle's International District: The Making of a Pan-Asian American Community. Seattle, WA: University of Washington Press.

Chin, Gordon. 2015. Building Community, Chinatown Style: a Half Century of Leadership in San Francisco Chinatown. San Francisco, CA: Friends of Chinatown Community Development Center.

Chris, Chu and Asian American Communication Experience. 1977. Bay Area Asian Human Service Directory. Technical report. San Francisco: Asian American Communication Experience.

Cinelli, C, and C Hazlett. 2019. "Sensemakr: Sensitivity Analysis Tools for OLS.” $R$ package Version 0.12.

Cook, R Dennis. 1977. "Detection of Influential Observation in Linear Regression." Technometrics 19 (1): 15-18.

Cook, Thomas D., and Donald Thomas Campbell. 1979. Quasi-experimentation: Design and Analysis Issues for Field Settings. Boston, MA: Houghton Mifflin.

Coxe, Stefany, Stephen G West, and Leona S Aiken. 2009. "The Analysis of Count Data: A Gentle Introduction to Poisson Regression and Its Alternatives.” Journal of Personality Assessment 91 (2): 121-136.

Danziger, Sheldon, and Robert Haveman. 1981. “The Reagan Budget: A Sharp Break With the Past." Challenge 24 (2): 5-13.

Dawson, Michael C. 1994. Behind the Mule: Race and Class in African-American Politics. Princeton, NJ: Princeton University Press.

Duarte, Stella Pope. 2016. Raul H. Yzaguirre: Seated at the Table of Power : a Biography. Mesa, AZ: Latino Book Publisher.

Eisinger, Peter K. 1973. "The Conditions of Protest Behavior in American Cities." The American Political Science Review 67 (1): 11-28. 
Espiritu, Le Yen. 1992. Asian American Panethnicity: Bridging Institutions and Identities. Philadelphia, PA: Temple University Press.

Fox, John, and Sanford Weisberg. 2018. An R Companion to Applied Regression. Thousand Oaks: SAGE Publications.

Frey, William H., and Reynolds Farley. 1996. "Latino, Asian, and Black Segregation in US Metropolitan Areas: Are Multiethnic Metros Different.” Demography 33 (1): 35-50.

Gardner, William, Edward P Mulvey, and Esther C Shaw. 1995. "Regression Analyses of Counts and Rates: Poisson, Overdispersed Poisson, and Negative Binomial Models.” Psychological bulletin 118 (3): 392.

Garza, Edward Daniel. 1951. "LULAC: League of United Latin American Citizens.” PhD diss., Southwest Texas State University.

Harrington, Michael. 1962. The Other America. New York: Simon / Schuster.

Herrera, Juan Carlos. 2013. "Nonprofits in Production: Race, Place, and the Politics of Care." PhD diss., Ethnic Studies, University of California, Berkeley.

Hirschman, Charles. 1987. "The Meaning and Measurement of Ethnicity in Malaysia: An Analysis of Census Classifications.” The Journal of Asian Studies, 555-582.

Hosokawa, Bill. 1982. JACL in Quest of Justice. New York: W. Morrow.

Ishizuka, Karen. 2016. Serve the People: Making Asian America in the Long Sixties. London: Verso Books.

Kim, Claire Jean. 1999. "The Racial Triangulation of Asian Americans.” Politics \& Society 27 (1): $105-138$. 2003. Bitter Fruit: The Politics of Black-Korean Conflict in New York City. Yale University Press. 
Kim, Jae Yeon. 2020. "Racism Is Not Enough: Minority Coalition Building in San Francisco, Seattle, and Vancouver." Studies in American Political Development, 1-21.

Kleiber, Christian, Kurt Hornik, Friedrich Leisch, and Achim Zeileis. 2002. "Strucchange. An R Package for Testing for Structural Change in Linear Regression Models.” Journal of Statistical Software 7 (2): 1-38.

Kohler, Scott. 2007. "Bedford-Stuyvesant and the Rise of the Community Development Corporation." In Casebook for the Foundation: A Great American Secret, edited by Joel L Fleishman, J Scott Kohler, and Steven Schindler. New York: Public Affairs.

Kuramoto, Ford H. 1976. "Lessons Learned in Federal-Funding Game.” Social Casework 57 (3): $208-218$.

Lozano, Rosina. 2018. An American Language: the History of Spanish in the United States. University of California Press.

Marquez, Benjamin. 1993. LULAC: The Evolution of a Mexican American Political Organization. Austin, TX: University of Texas Press.

Martınez, Deirdre. 2008. Who Speaks for Hispanics?: Hispanic Interest Groups in Washington. Albany: SUNY Press.

McAdam, Doug. 1982. Political Process and the Development of Black Insurgency, 1930-1970. Chicago, IL: University of Chicago Press.

Minkoff, Debra C. 1995. Organizing for Equality: The Evolution of Women's and Racial-Ethnic Organizations in America, 1955-1985. New Brunswick, NJ: Rutgers University Press.

—. 2002. "The Emergence of Hybrid Organizational Forms: Combining Identity-based Service Provision and Political Action." Nonprofit and Voluntary Sector Quarterly 31 (3): 377-401.

Mora, G Cristina. 2014. Making Hispanics: How Activists, Bureaucrats, and Media Constructed a New American. Chicago, IL: University of Chicago Press. 
Muñoz, Carlos. 1989. Youth, Identity, Power: The Chicano Movement. London: Verso Books.

Nagata, Judith A. 1979. Malaysian Mosaic: Perspectives from a Polyethnic Society. Vancovuer: University of British Columbia Press.

Naples, Nancy A. 1998. "From Maximum Feasible Participation to Disenfranchisement." Social Justice 25 (1 (71)): 47-66.

Nnoli, Okwudiba. 1978. Ethnic Politics in Nigeria. Enugu, Nigeria: Fourth Dimension Publishers.

O'Connor, Alice. 1996. "Community Action, Urban Reform, and the Fight Against Poverty: The Ford Foundation's Gray Areas Program." Journal of Urban History 22 (5): 586-625.

Okamoto, Dina, and G Cristina Mora. 2014. "Panethnicity." Annual Review of Sociology 40:219_ 239.

Okamoto, Dina G. 2014. Redefining Race: Asian American Panethnicity and Shifting Ethnic Boundaries. New York: Russell Sage Foundation.

Omi, Michael, and Howard Winant. 1986. Racial Formation in the United States: from the 1960s to the 1990s. New York: Routledge.

Orleck, Annelise. 2011. "The War on Poverty from the Grass Roots Up.” In The War on Poverty: a New Grassroots History, 1964-1980, edited by Annelise Orleck and Lisa Gayle Hazirjian. Athens, GA: University of Georgia Press.

Orleck, Annelise, and Lisa Gayle Hazirjian, eds. 2011. The War on Poverty: A New Grassroots History, 1964-1980. Athens, GA: University of Georgia Press.

Orozco, Gabriel, Sara L Schwartz, and Michael J Austin. 2011. "The Unity Council at 40: A Pioneering Community Development and Service Organization (1967-2007)." Journal of Evidence-based Social Work 8 (1-2): 45-65.

Padilla, Felix M. 1985. Latino Ethnic Consciousness: the Case of Mexican Americans and Puerto Ricans in Chicago. Notre Dame, IN: University of Notre Dame Press. 
Pierson, Paul. 1994. Dismantling the Welfare State?: Reagan, Thatcher and the Politics of Retrenchment. New York: Cambridge University Press.

Pressman, Jeffrey L. 1975. Federal Programs and City Politics: The Dynamics of the Aid Process in Oakland. Berkeley, CA: University of California Press.

Quesada, James. 1999. "From Central American Warriors to San Francisco Latino Day Laborers: Suffering and Exhaustion in a Transnational context." Transforming Anthropology 8 (1-2): $162-185$.

Rodriguez, Clara E. 2000. Changing Race: Latinos, the Census, and the History of Ethnicity in the United States. New York: NYU Press.

Santos, Bob. 2002. Humbows, Not Hot Dogs: Memoirs of a Savvy Asian American Activist. Seattle, WA: International Examiner press.

Santos, Robert, and Gary Iwamoto. 2015. Gang of Four: Four Leaders. Four Communities. One Friendship. Seattle, WA: Chin Music Press.

Savin, Nathan E, and Kenneth J White. 1977. "The Durbin-Watson Test for Serial Correlation with Extreme Sample Sizes or Many Regressors.” Econometrica: Journal of the Econometric Society, 1989-1996.

Schattschneider, Elmer Eric. 1935. Politics, Pressures and the Tariff. New York: Prentice-Hall.

Scott Long, John. 1997. Regression Models for Categorical and Limited Dependent Variables. Thousand Oaks: SAGE Publications.

Strolovitch, Dara Z. 2007. Affirmative Advocacy: Race, Class, and Gender in Interest Group Politics. Chicago, IL: University of Chicago Press.

Tate, Katherine. 1994. From Protest to Politics: The New Black Voters in American Elections. Cambridge, MA: Harvard University Press. 
The Boards of Trustees of the Federal Hospital Insurance and Federal Supplementary Medical Insurance Trust Funds. 2018. 2018 Annual Report of the Boards of Trustees of the Federal Hospital Insurance and Federal Supplementary Medical Insurance Trust Funds. Technical report.

Tichenor, Daniel J. 2009. Dividing Lines: The Politics of Immigration Control in America. Princeton, NJ: Princeton University Press.

Tilly, Charles. 1978. From Mobilization to Revolution. Reading, MA: Addison-Wesley.

Umbach, Greg, and Dan Wishnoff. 2008. "Strategic Self-Orientalism: Urban Planning Policies and the Shaping of New York City's Chinatown, 1950-2005.” Journal of Planning History 7 (3): 214-238.

Võ, Linda Trinh. 2004. Mobilizing an Asian American Community. Philadelphia, PA: Temple University Press.

Wei, William. 1993. The Asian American Movement. Philadelphia, PA: Temple University Press.

Wolman, Harold. 1986. “The Reagan Urban Policy and Its Impacts.” Urban Affairs Quarterly 21 (3): 311-335.

Wong, Bernard. 1977. "Elites and Ethnic Boundary Maintenance: A Study of the Roles of Elites in Chinatown, New York City." Urban Anthropology, 001-022.

Young, Crawford. 1976. The Politics of Cultural Pluralism. Madison, WI: University of Wisconsin Press.

Zeileis, Achim, Christian Kleiber, Walter Krämer, and Kurt Hornik. 2003. "Testing and Dating of Structural Changes in Practice." Computational Statistics \& Data Analysis 44 (1-2): 109-123.

Zepeda-Millán, Chris. 2017. Latino Mass Mobilization: Immigration, Racialization, and Activism. Cambridge, MA: Cambridge University Press. 


\section{Online Appendix}

\section{Appendix A War on Poverty Programs}

The OEO used the following formula to allocate federal grants in state $s$ at year $t$ :

$$
\text { PovertyIndex }_{s t}=\frac{1}{3} U E_{s t}+\frac{1}{3} P A_{s t}+\frac{1}{3} P K_{s t}
$$

UE indicates the state's share of the national number of unemployed. PA represents the state's share

of the national public assistance recipients. PK refers to the state's share of poor children (Bailey and Danziger 2013, 11-12). 


\section{Appendix B Organizations}

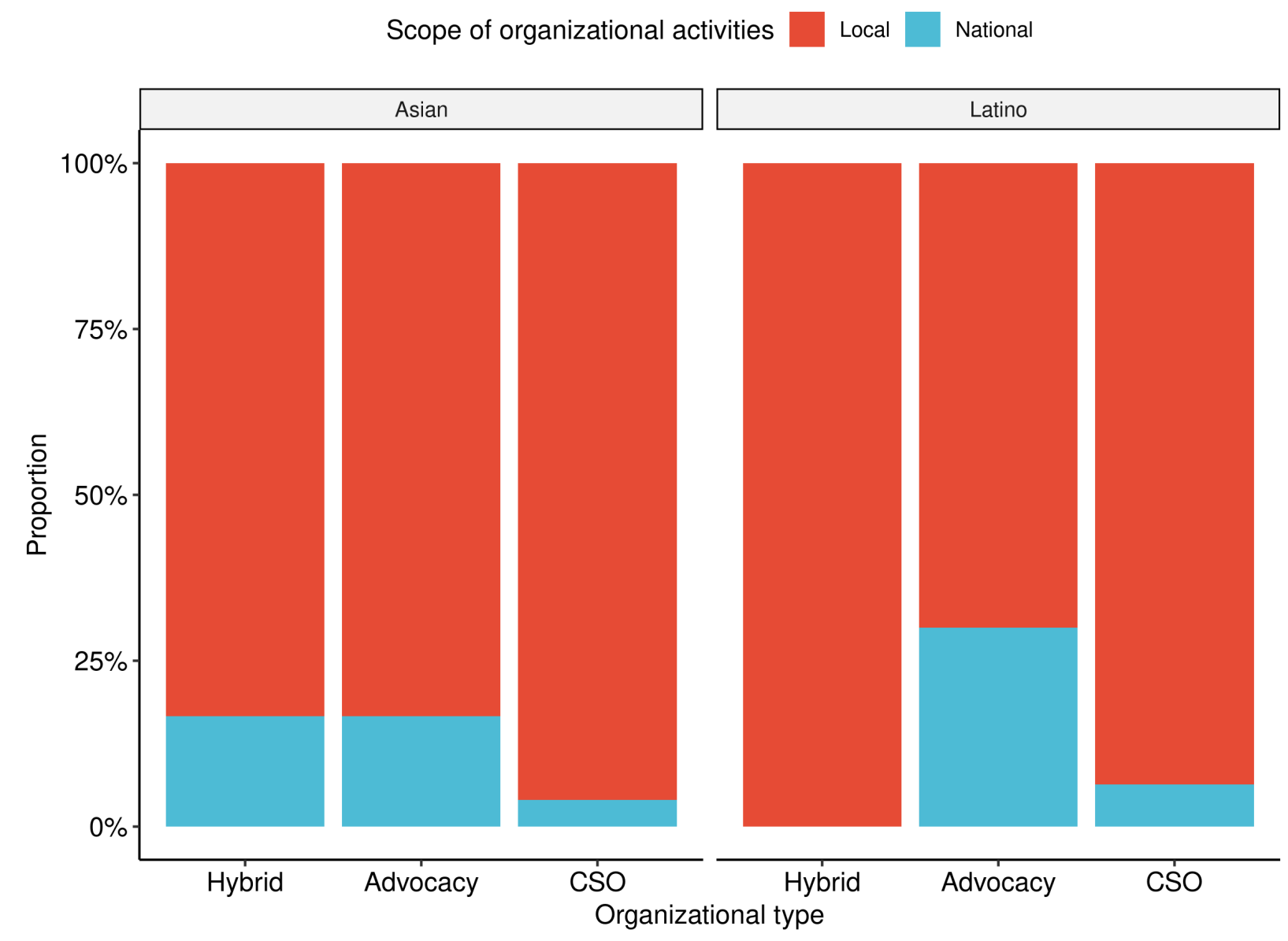

Figure B.1: Asian American and Latino organizations sorted by their scope of their activities and types, 2017. Source: the author 


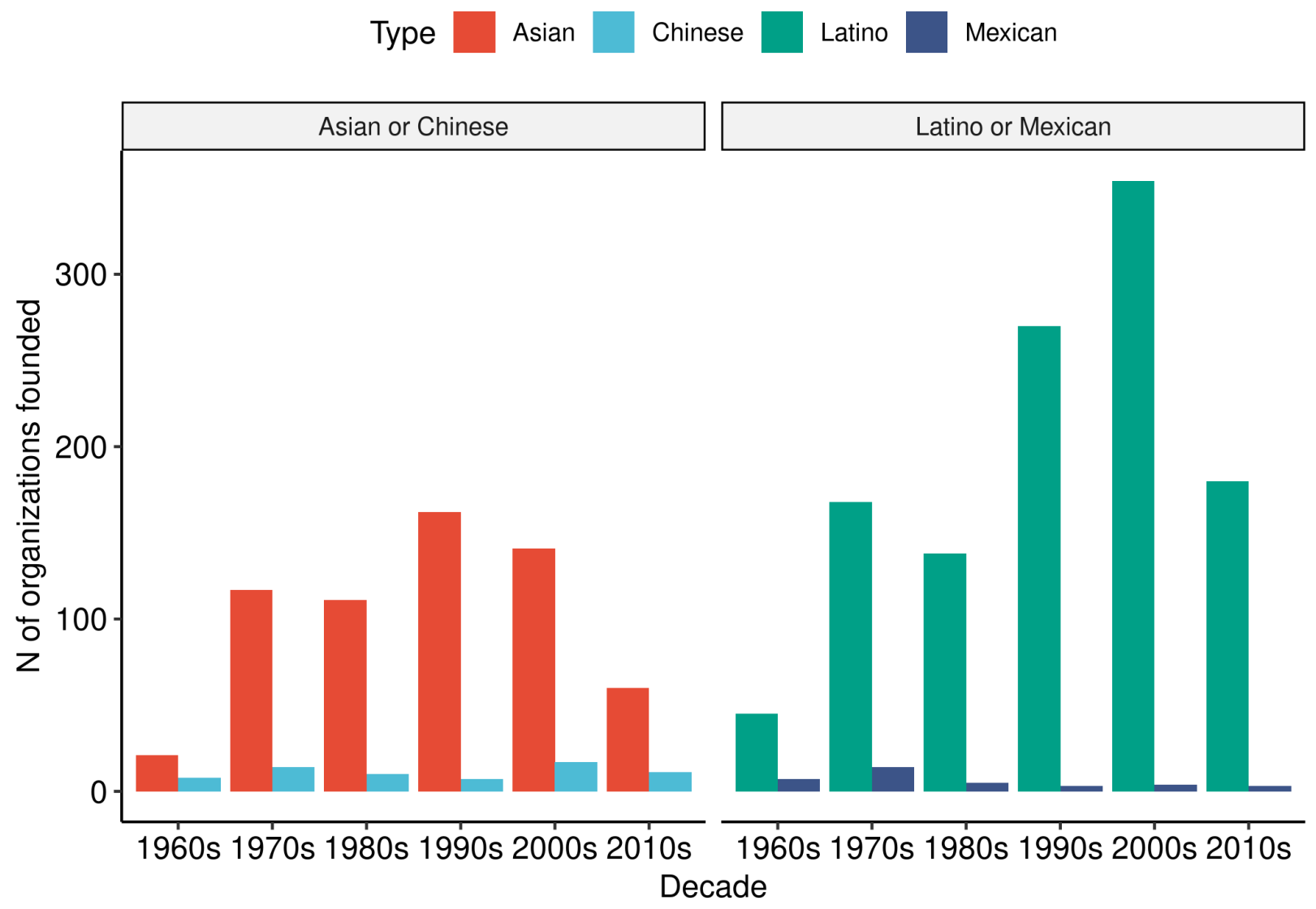

Figure B.2: The founding trends of panethnic and ethic CSOs, 1960 - 2017. Source: the author 


\section{Appendix C Organizational Data Coding}

\section{Subsection C.1 Including Ethnic Organizations Evolved into Panethnic Or- ganizations}

For instance, the NCLR started as a regional organization focused on Mexican Americans in 1968 in Phoenix, Arizona. It began to officially focus on non-Mexican issues only in the mid-1970s. Its transition was intentionally gradual because the organization needed to negotiate simultaneously with its old supporters and new partners (Mora 2014, 57). For this historical reason, the proportion of such gradually evolved panethnic organizations is greater among those founded earlier than the others in the dataset. Overall, this type of organization consists of only $7 \%$ of the Asian American organizations and $12 \%$ of the Latino ones in the dataset. Conversely, the proportion of those organizations founded in the 1960s and 1970s goes up to $22 \%$ on the Asian American and $32 \%$ on the Latino side. Including these organizations in the dataset is crucial to avoid undermining the extent of Asian American and Latino community organizing during these early decades. Ideally, I would like to have information on when exactly these organizations turned into panethnic ones. Unfortunately, archival resources on these organizations are scarce and non-systematic. As a result, I use their founding years as a proxy variable.

\section{Subsection C.2 Verifying Panethnic Organizations}

To verify whether these are indeed panethnic organizations in their names as well as their programs and activities, I visited their websites. Except for a handful of well-known organizations (e.g., the NCLR), most of these organizations' internal materials are not publicly available. Using their websites is limited but is one of the feasible ways to collect information of interest. I checked whether the organizations claimed to be panethnic in their mission statements or served broader ethnic groups than one national origin group in their project descriptions. When an organization did not have a website, I searched news sites for more information. I used the same validation method in terms of classifying whether an organization is an advocacy, community service, or 
hybrid organization to determine the year in which each organization was founded, rather than the year of their incorporation according to Internal Revenue Service (IRS) records. I was able to locate about $77 \%$ of the Asian and $71 \%$ of the Latino organizations' founding years in this way. If these data were not available, I then emailed the staff at these organizations.

\section{Subsection C.3 Validating with Other Data Sources}

The Bay Area Human Service Directory, compiled by local Asian American social workers and published in 1977, identified eight Asian human service organizations in San Francisco (Chris, Chu and Asian American Communication Experience 1977). One of these, the International Institute of San Francisco, serves non-English-speaking immigrants, not necessarily Asian populations. Except for this, my dataset missed two out of seven organizations, the Asian Community Center and the San Francisco Bay Area Asian American Community Mental Health Training Center. Nonetheless, I suspected that this $30 \%$ missing data rate could be an exception rather than the norm because San Francisco, the birthplace of the Asian American movement, has an unusually long history of Asian American activism. 


\section{Appendix D Philanthropic Giving}

Philanthropic giving was an important but limited funding source for Asian American and Latino community organizers in the 1960s and 1970s. As past studies argued (Kuramoto 1976; Espiritu 1992; Orozco, Schwartz, and Austin 2011), big foundations tended to grant monies to a selective few well-known large organizations. The Ford Foundation was one of the largest foundations in the world in the 20th century, and it invested heavily in remedying urban poverty (O'Connor 1996; Kohler 2007). I used their grant records, available at the Rockefeller Archive Center, as a partial measure to estimate the influence of large foundations on Asian American and Latino community organizing. I tracked which organizations in my dataset received funds from the Ford Foundation from 1960 to 1980 and identified only six among the 166 organizations listed. The result confirms the limited scope of philanthropic giving. 


\section{Appendix E Federal Funding}

Figure E.1 displays the percentage difference between the pre-Reagan baseline and the actual federal outlays for these programs in 1982. The budgets for all these programs showed a sharp decline. Particularly critical was the termination of the Community Services Administration ${ }^{28}$ and the Comprehensive Training and Employment Act, which were used by these organizations to pay their employees (Santos 2002; Santos and Iwamoto 2015).

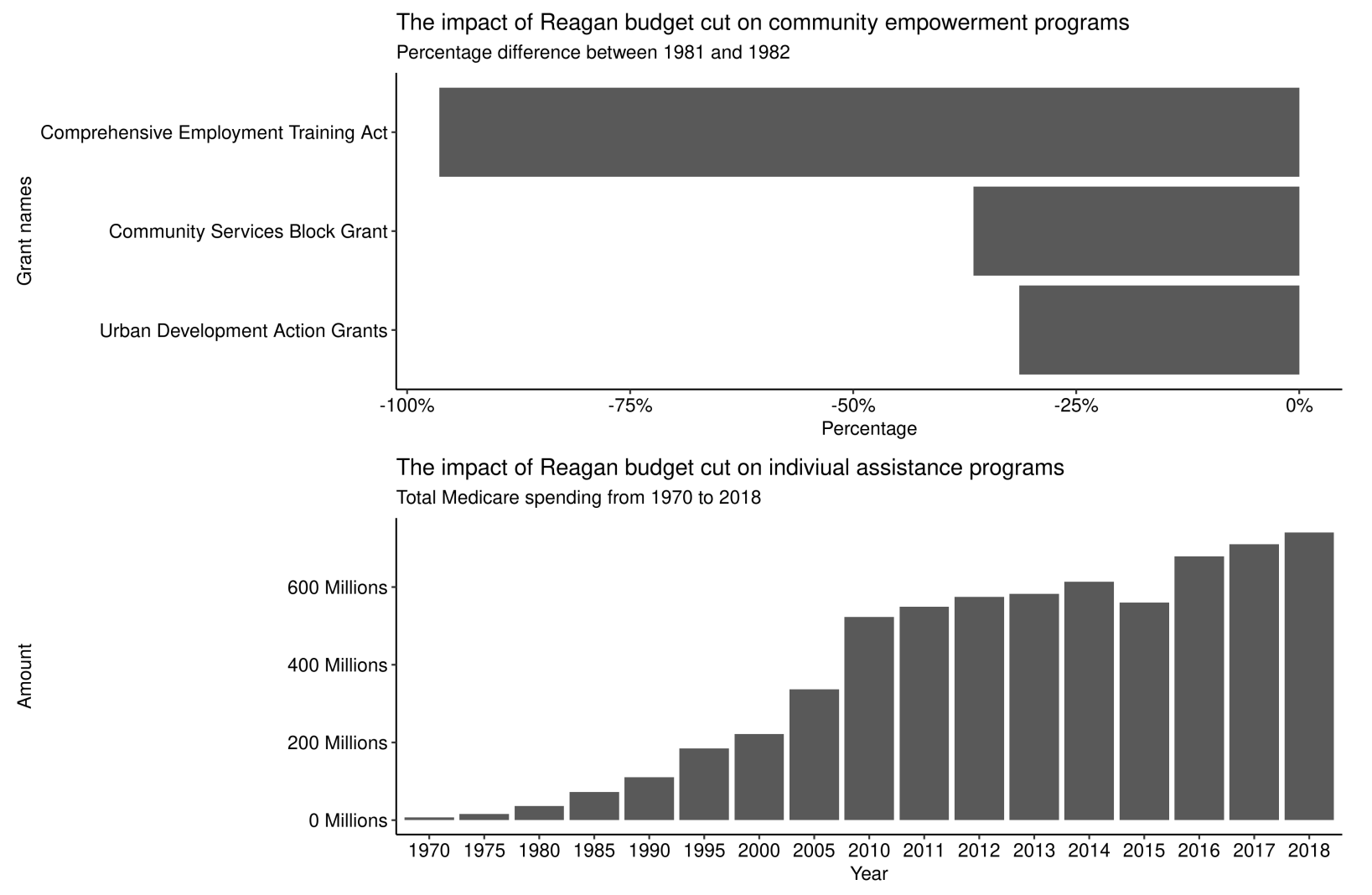

Figure E.1: The differential impacts of the Reagan budget cut. Sources: Wolman $(1986,318)$, originally from unpublished Congressional Budget Office tabulations, and The Boards of Trustees of the Federal Hospital Insurance and Federal Supplementary Medical Insurance Trust Funds (2018)

28. Nixon administration renamed the Office of Economic Opportunity the Community Services Administration in 1975. 


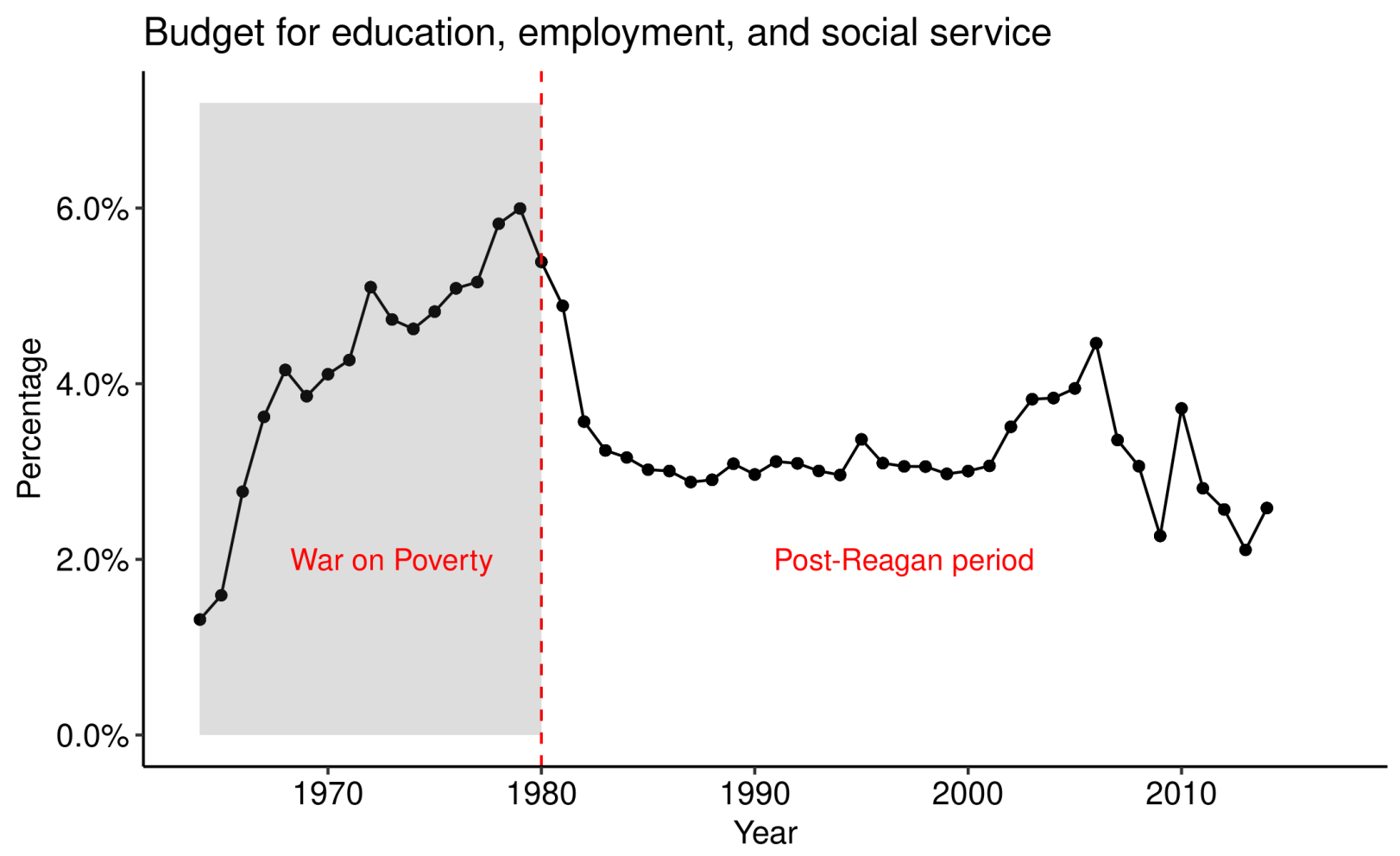

Figure E.2: Federal budgets for education, employment and social service, 1964-2014. Sources: Budget of the U.S. Government, Fiscal year 2017 Historical Tables. 


\section{Appendix F Community Response}

The Ethnic NewsWatch database ${ }^{29}$ contains all 3,120 articles published by the The International Examiner from 1976 through 1987. Agenda was available only as printed copies held in the Chicano Collection at the Ethnic Studies Library at the University of California, Berkeley. I scanned and digitized all these newsletters published from 1971 through $1981 .^{30}$ The number of pages totaled 1,249. ${ }^{31}$ Only 141 articles in The International Examiner and 49 pages in Agenda mentioned Reagan at least once. Almost all these articles or pages appeared after Reagan announced his plan to reduce social expenditures in 1981. I also note how frequently budget-related terms ${ }^{32}$ are mentioned in the articles or pages about Reagan using a dictionary-based text analysis method.

29. For more information, see https://www.proquest.com/products-services/ethnic_newswatch.html 30. Agenda became inactive between 1982 and 1988. Publication resumed in 1989.

31. I wrote an R script to automatically parse text information from these more than 1,000 scanned images. It was difficult to separate articles from pages as the scanned images were highly unstructured. For this reason, each page was taken as a unit of observation in this data.

32. These budget-related terms are "spending," "grants," "grant," "funding," "funds," and "fund." 

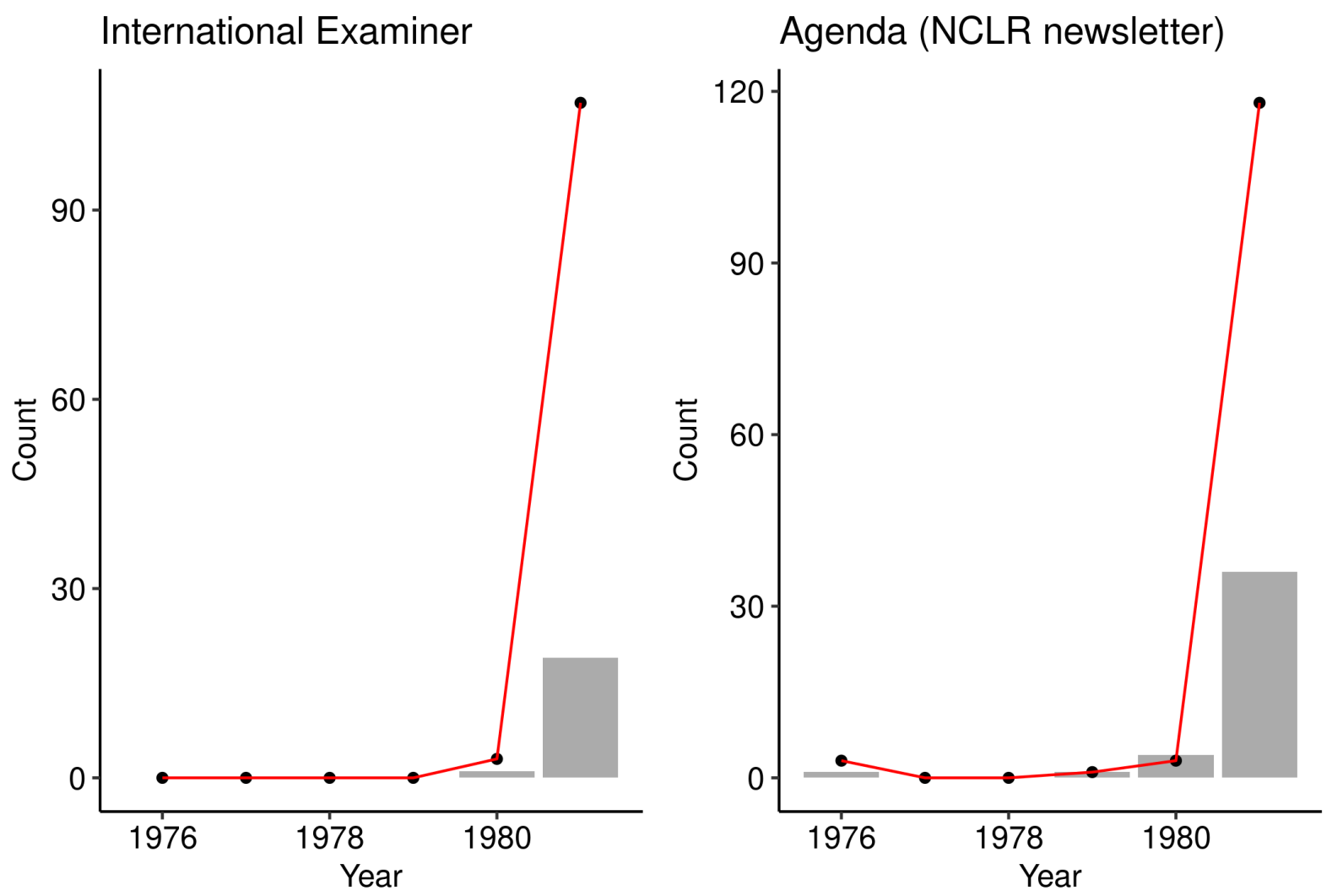

Figure F.1: The number of Reagan-related articles (bar plots) and the frequency of budget-related terms in a Reagan related article (point and line plots) in The International Examiner and Agenda, 1976-1981. Sources: Ethnic NewsWatch and Chicano Studies Collection, UC Berkeley Ethnic Studies Library 


\section{Appendix G Change Point Estimation}

In a segmented regression model fitted to time series data, a change point is an abrupt variation in the data that indicates a time point when the regression coefficients become unstable. I built a linear regression model that regresses logged organizational founding rate on the interaction term between year and intervention and the organization type variables. This is the same as the reduced version of the estimation model, which will be described in the following paragraph. I then fitted this model to the data and estimated the second change point using the strucchange package in $\mathrm{R}$ (Kleiber et al. 2002). 


\section{Appendix H Outlier Detection}

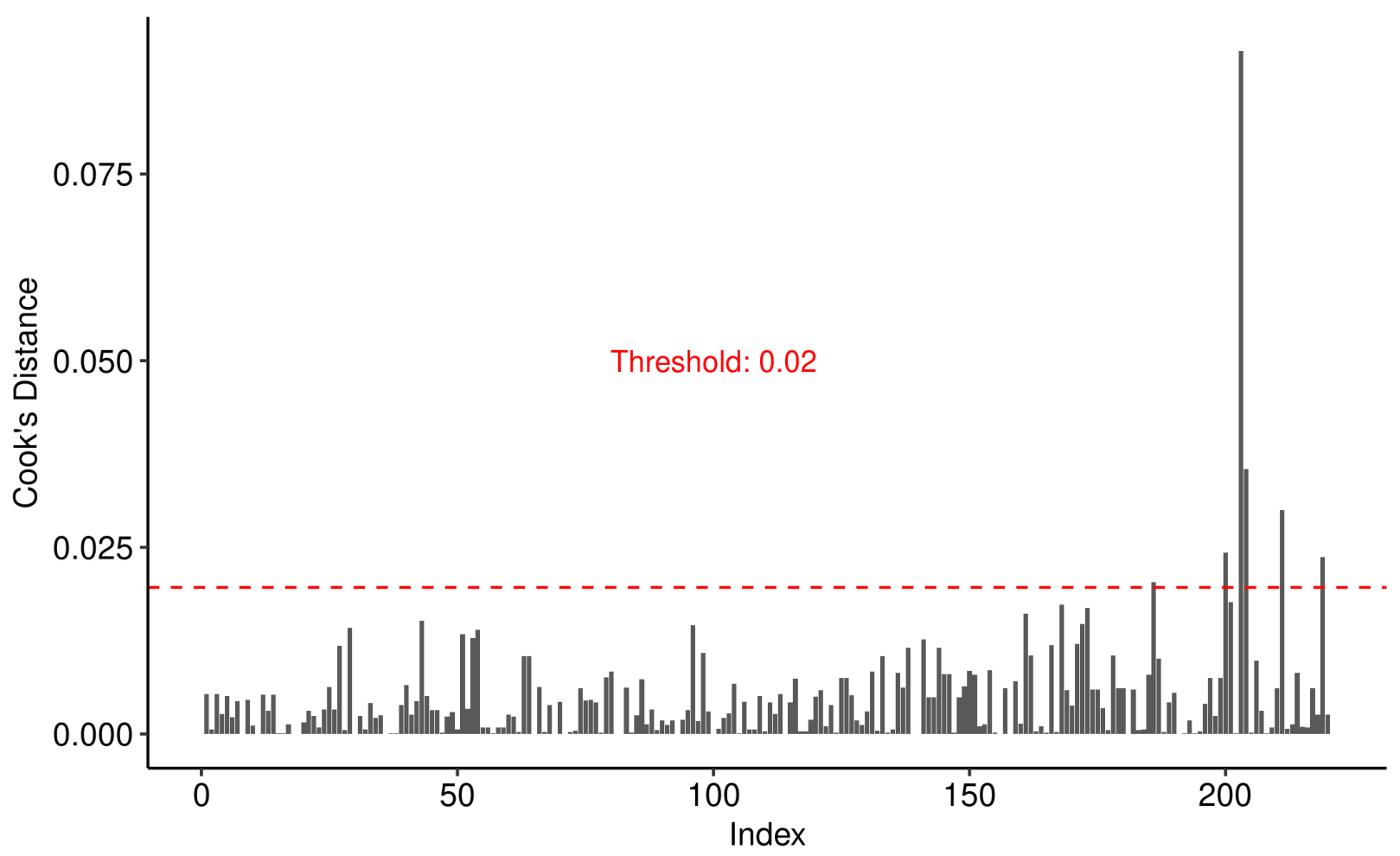

Figure H.1: Outlier detection

I first log-transformed the dependent variable because some outliers could be resolved by transforming the dependent variable. I then used a multivariate regression model, as specified in Model 2, to draw a regression line and identified outliers based on Cook's Distance, which measures an observation's influence on a linear regression (Cook 1977). I removed these outliers and imputed new values using the k-nearest neighbors algorithm to reduce their influence. In Figure H.1, the Y-axis indicates Cook's distance, and the X-axis indicates the observation numbers (the row index in the dataset). A greater observation number indicates a more recent year observation. Outliers are those observations with a Cook's distance of more than four times of the mean. The Cook's distance was calculated by the car package (Fox and Weisberg 2018). 


\section{Appendix I Model Selection}

Various regression models can be fitted to the data. If the dependent variable is conceptualized as a continuous variable, an ordinary least squares (OLS) model would work. However, the base model is naïve, as many of its assumptions are easily violated. An OLS model assumes linearity and homoscedasticity (or constant variance). However, Figure 1 shows that the organizational founding patterns are neither closely linear nor stable. As such, regression coefficients could be biased. In addition, the mean of the dependent variable is low. The average frequency of organizational founding is 2 for advocacy and hybrid organizations and 5 for CSOs. In this case, the OLS model yields biased standard errors, which increase the type I error rate (false positives) (Gardner, Mulvey, and Shaw 1995; Scott Long 1997). Log-transforming the dependent variable could make the relationship between the dependent variable and the predictors more linear, but the other problems may persist. If these violations are the focus, conceptualizing the dependent variable as a count variable and using a Poisson model would be a better approach. The Poisson model is a family of the generalized linear model that is flexible enough to deal with non-linear data. In addition, the Poisson model is suitable to model count data because the Poisson distribution is a family of exponential distribution, which captures a growth pattern easily. Nevertheless, the model has a limitation, as it assumes that the mean and variance of the distribution are equal. This assumption is only useful if the mean and variance increase simultaneously (Coxe, West, and Aiken 2009, 122-124). A negative binomial model deals with this problem by including a random term, which reflects the unexplained variance between subjects, in the Poisson model (Gardner, Mulvey, and Shaw 1995).

In Figure I.1, the blue plotted line indicates the predicted values $(\hat{Y})$. The gray ribbons around the line plot display two standard errors, which are approximate to $95 \%$ confidence intervals. Based on the AIC scores, the OLS model with a logged dependent variable fits the data best (344.842). The naive OLS model performs the worst (712.282). The Poisson (612.795) and the negative binomial models (614.797) perform similarly. I selected the OLS with a logged dependent variable because a lower AIC score indicates a less overfitting model. 

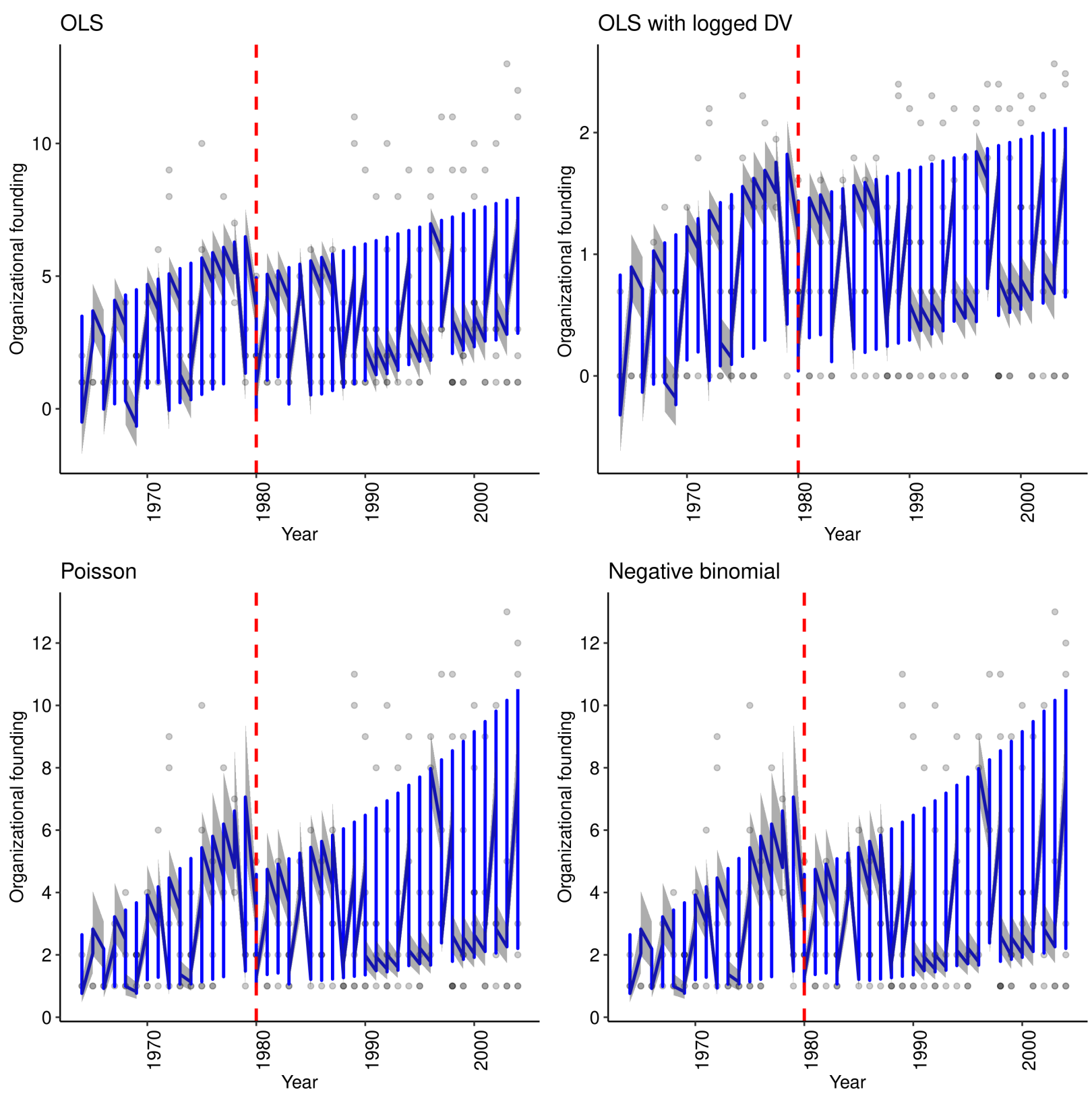

Figure I.1: Fitting models to the data 


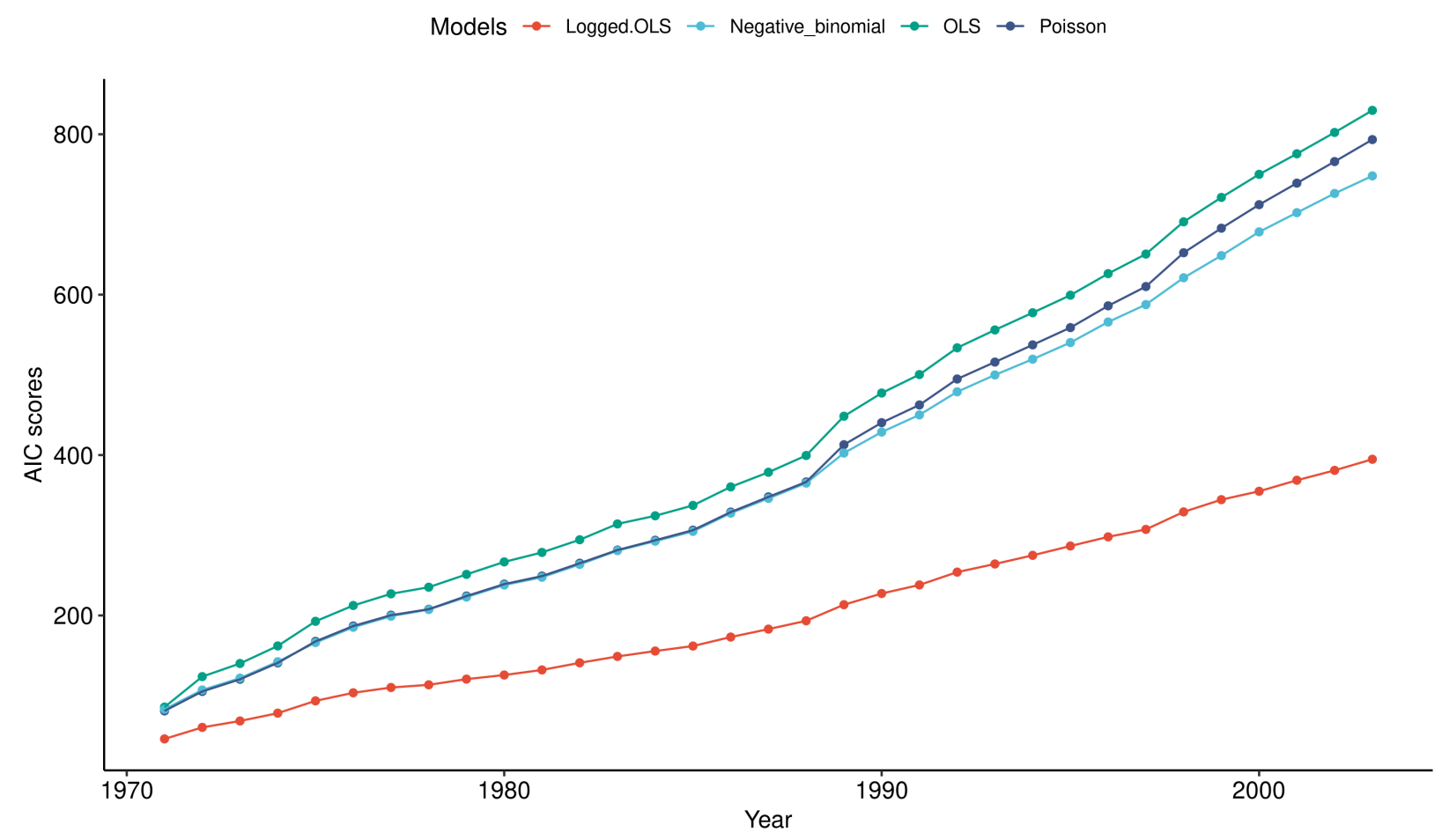

Figure I.2: Fitting models to the data over time

Some models may fit for a short-term period, whereas others do better for a long-term period. To address this concern, I checked how the AIC scores of these four models varied as I extended the data from the year 1970 to 2004 . Figure I.2 indicates that the OLS model with a logged dependent variable consistently outperformed the OLS, Poisson, and negative binomial models. 


\section{Appendix J Model Specification}

Specifically, I use Model 2 to estimate how the coefficient of federal funding variable changes as I extend the data from the year 1970 to 2004 . In the model, X measures the percentage of the federal budget for education, employment, and social services, and the population variable measures the percentage of Asian American or Latino population at time $t$. The group category variable is defined as above. Presidency, Senate, and House indicate which party controls the presidency, the Senate, and the House (the Democratic Party $=1$, the Republican Party =0). I fit an OLS, an OLS with logged dependent variable, a Poisson, and a negative binomial model to the data and select the one that fits it best given its AIC score. 


\section{Appendix K Robustness Checks}

An OLS model assumes homoscedasticity. I ran the studentized Breusch-Pagan test (Breusch and Pagan 1979) and showed that this assumption does not hold. The null hypothesis of the test is that the variance of residuals is constant (homoscedasticity). However, the p-value of the test result is 0.04. In addition, an OLS model assumes independent random errors. In time series data, this assumption is easily violated because autocorrelation (or serial correlation) is a pervasive problem. The autocorrelation test (ACF) result shows the correlation between the time series and its lagged values (see Figure K.1). None of the correlation coefficients are statistically significant (no bar graph above or below the dashed line). I also ran the Durbin-Watson test, which checks the autocorrelation of residuals (Savin and White 1977). The test also fails to reject the null hypothesis. Therefore, I was worried about heteroskedasticity but not autocorrelation. I was also concerned about outliers. Previously, I defined outliers as those observations with a Cook's distance of more than four times of the mean. I treated these outliers, but the threshold bar could be too low. The remaining outliers may bias the regression coefficients and standard errors. 


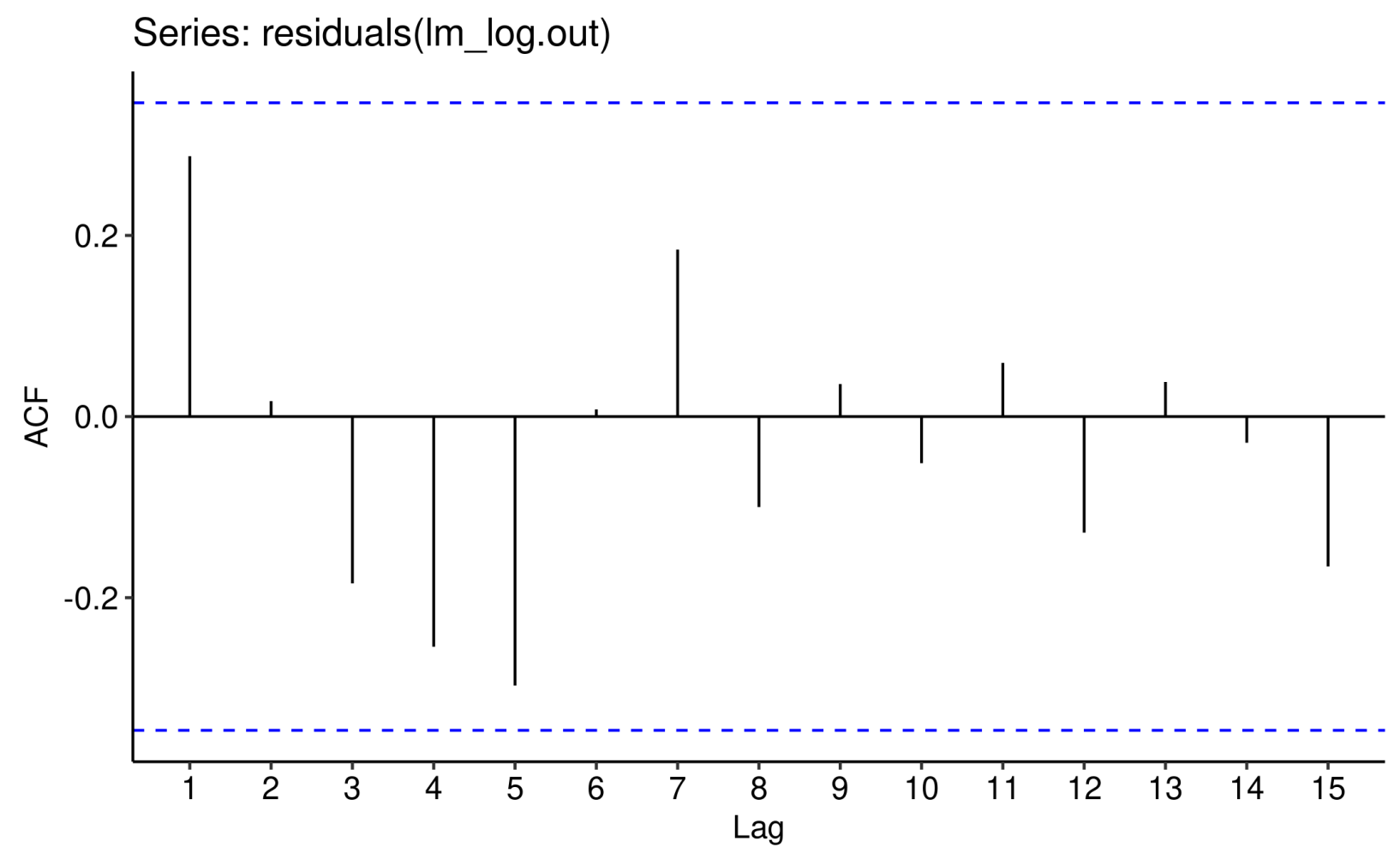

Figure K.1: Autocorrelation test 


\section{Appendix L Omitted Variable Bias}

I used an OLS with logged dependent variable model. I fitted the OLS, the Poisson, and the negative binomial model to the data. The OLS with logged dependent variable outperformed the others based on their relative AIC scores. Table L. 1 shows the result. Model 1 is the base model which only includes the group category. Model 2 adds county-level demographic covariates, namely the percentage of Asian and Latino populations. Model 3 adds the county-level poverty rate covariate. Model 4 follows the specification used in Model 3 but uses Huber-White standard errors to account for heteroscedastic residuals. The OEO grants variable is statistically significant (p-value $<0.01)$, the coefficient is also only marginally different, and its sign is positive across the four models. To help interpret, the OEO grants were recalculated as proportions in the model: A OEO grant in a county $i$ is divided by the sum of the OEO grants in all of the counties in the data.

\begin{tabular}{|c|c|c|c|c|}
\hline & \multicolumn{4}{|c|}{ Dependent variable: } \\
\hline & \multicolumn{3}{|c|}{ Cumulative founding in 1981 (logged) } & \multirow{3}{*}{$\begin{array}{c}\text { OLS } \\
\text { with robust SEs } \\
\text { Model } 4\end{array}$} \\
\hline & & $O L S$ & & \\
\hline & Model 1 & Model 2 & Model 3 & \\
\hline OEO grants & $0.259^{* * *}(0.078)$ & $0.244^{* * *}(0.081)$ & $0.245^{* * *}(0.082)$ & $0.245^{* * *}(0.074)$ \\
\hline Latino org & $-0.431^{* * *}(0.137)$ & $-0.401^{* * *}(0.146)$ & $-0.404^{* * *}(0.149)$ & $-0.404^{* *}(0.184)$ \\
\hline Asian pop & & $0.004(0.008)$ & $0.004(0.008)$ & $0.004(0.015)$ \\
\hline Latino pop & & $0.004(0.006)$ & $0.004(0.007)$ & $0.004(0.007)$ \\
\hline Poverty rate & & & $-0.002(0.013)$ & $-0.002(0.011)$ \\
\hline Constant & $0.477^{* * *}(0.138)$ & $0.412^{* *}(0.161)$ & $0.428^{* *}(0.206)$ & $0.428^{* *}(0.209)$ \\
\hline Observations & 76 & 76 & 76 & \\
\hline $\mathrm{R}^{2}$ & 0.253 & 0.260 & 0.260 & \\
\hline Adjusted $\mathrm{R}^{2}$ & 0.232 & 0.218 & 0.207 & \\
\hline
\end{tabular}

Table L.1: Cross-sectional regression analysis 